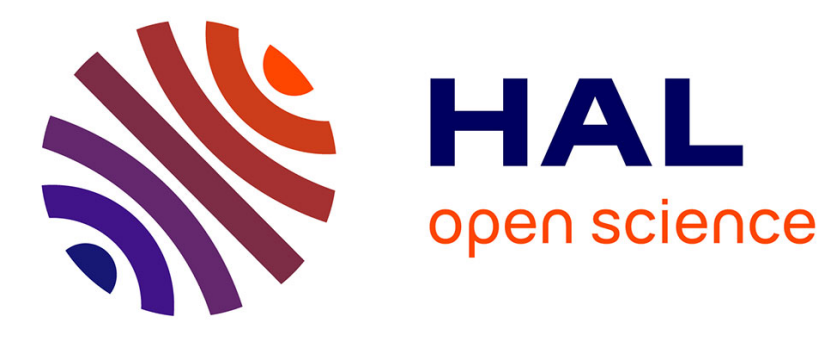

\title{
Star-Shaped Ruthenium Complexes as Prototypes of Molecular Gears
}

\author{
Guillaume Erbland, Seifallah Abid, Yohan Gisbert, Nathalie Saffon-merceron, \\ Yuichiro Hashimoto, Leonardo Andreoni, Théo Guérin, Claire Kammerer, \\ Gwénaël Rapenne
}

\section{To cite this version:}

Guillaume Erbland, Seifallah Abid, Yohan Gisbert, Nathalie Saffon-merceron, Yuichiro Hashimoto, et al.. Star-Shaped Ruthenium Complexes as Prototypes of Molecular Gears. Chemistry - A European Journal, 2019, 25, pp.16328. 10.1002/chem.201903615 . hal-02417240

\author{
HAL Id: hal-02417240 \\ https://hal.science/hal-02417240
}

Submitted on 12 May 2020

HAL is a multi-disciplinary open access archive for the deposit and dissemination of scientific research documents, whether they are published or not. The documents may come from teaching and research institutions in France or abroad, or from public or private research centers.
L'archive ouverte pluridisciplinaire HAL, est destinée au dépôt et à la diffusion de documents scientifiques de niveau recherche, publiés ou non, émanant des établissements d'enseignement et de recherche français ou étrangers, des laboratoires publics ou privés. 


\title{
Star-shaped ruthenium complexes as prototypes of molecular gears
}

\author{
Guillaume Erbland, ${ }^{[a]}$ Seifallah Abid, ${ }^{[a]}$ Yohan Gisbert, ${ }^{[a]}$ Nathalie Saffon-Merceron, ${ }^{[b]}$ Yuichiro \\ Hashimoto, ${ }^{[\mathrm{cc}}$ Leonardo Andreoni, ${ }^{[\mathrm{a}]}$ Théo Guérin, ${ }^{[\mathrm{a}]}$ Claire Kammerer, ${ }^{[\mathrm{a}]}$ and Gwénaël Rapenne ${ }^{*[\mathrm{a}, \mathrm{c}]}$
}

[a] CEMES, Université de Toulouse, CNRS, 29, rue Jeanne Marvig, 31055 Toulouse, France

E-mail: rapenne@cemes.fr

http://www.cemes.fr/rapenne

[b] Université de Toulouse, UPS, Institut de Chimie de Toulouse, ICT FR 2599,

118 route de Narbonne, 31062 Toulouse, France

[c] Division of Materials Science, Nara Institute of Science and Technology, 8916-5 Takayama,

Ikoma, Nara, Japan

Dedicated to Professor Jean-Pierre Sauvage on the occasion of his $75^{\text {th }}$ birthday

\begin{abstract}
The design and synthesis of two families of molecular gears prototypes is reported, with the aim of assembling them into trains of gears on surface and ultimately achieving controlled intermolecular gearing motion. These piano-stool ruthenium complexes incorporate a hydrotris(indazolyl)borate moiety as tripodal rotation axle and a pentaarylcyclopentadienyl ligand as star-shaped cogwheel, equipped with five teeth ranging from pseudo 1-dimensional aryl groups to large planar 2-dimensional paddles. A divergent synthetic approach was followed, starting from a penta( $p$ bromophenyl)cyclopentadienyl ruthenium(II) complex as key precursor or from its iodinated counterpart, first obtained by copper-catalyzed aromatic Br/I exchange. Subsequent five-fold crosscoupling reactions with various partners allowed high structural diversity to be reached, yielding molecular gears prototypes displaying aryl-, carbazole-, BODIPY- and porphyrin-derived teeth of increasing size and length.
\end{abstract}

\section{Keywords}

cross-coupling $\bullet$ cyclopentadienyl ligands $\bullet$ molecular gears $\bullet$ molecular machines $\bullet$ ruthenium

Preprint

Submitted to Chem. Eur. $J$ 


\section{Introduction}

For four decades, molecular gears have stimulated the imagination of synthetic chemists. In 1980, Iwamura $^{[1]}$ and Mislow $^{[2]}$ were the first to independently report molecular gears consisting of two triptycene subunits close enough to interact with each other in a bevel gear fashion. In 1997, C.J. Richards published an organometallic metallocene molecular gear with a cobalt ion gathering together a tetraphenylcyclobutadiene wheel in close contact with a triptycene, therefore displaying $3 \times 4$ gearing ratio. ${ }^{[3]}$ In 2012 Siegel et al. again used triptycene units in a different design mimicking spur gears with a special focus on the optimal interaxle distance leading to correlated disrotatory gearing motion. ${ }^{[4]}$ Five years later, Shionoya et al. reported a Pt(II)-centered molecular gear, in which the two azaphosphatriptycene cogwheels were very elegantly engaged or disengaged via cis-trans isomerization processes around the platinum center. ${ }^{[5]}$ In all these examples, coordinated motions have been evidenced in solution, which limits the number of cogwheels possibly inter-digitated and where unidirectionality is not achievable due to the second law of thermodynamics and Brownian motion. The drawbacks of these studies in solution strongly limit the potentialities of such molecular machines.

While Nature uses the anisotropy of the cell's membrane to overcome the second law of thermodynamics, our strategy is to orient molecules for deposition of molecular gears on surfaces. Thus, it becomes possible to deal with multimolecular gearing systems, each molecule being considered as a single gear. After deposition, one could build a large variety of trains of gears with very good control over the intermolecular distance between neighbouring molecules. Dealing with linear assemblies of molecules allows us to follow the transmission of motion from one molecule to another, which is impossible in solution where gearing mechanisms are restricted to intramolecular correlated rotations.

The first demonstration of intermolecular gearing motion on a surface was achieved by Moresco et al. in a rack and pinion device. ${ }^{[6]}$ They used a star-shaped molecule of penta( $p$-tert-butylphenyl)-(p-tertbutylpyrimido)benzene which was moved laterally with the tip of a Scanning Tunneling Microscope (STM) along the edge of an island of the same molecules on $\mathrm{Cu}(111)$. The rotation of this single molecule was evidenced on successive STM images by following the motion of the contrasting nitrogen atoms. Subsequent studies on $\mathrm{Au}(111)$ revealed that it is possible to achieve stepwise rotation of this star-shaped molecule at the single molecular level when mounted on a defect used as rotation axis. ${ }^{[7]}$ Unfortunately it has not been possible to transfer the rotary motion to another molecule in close proximity due to the preferred diffusion of the molecules on the surface. This seminal work highlighted the prime importance of anchoring molecular gears, thus precluding diffusion and providing a defined axis of rotation, as in the macroscopic world, to ultimately control intermolecular gearing on a surface.

Our strategy to avoid diffusion of a series of rotary molecular machines deposited on metallic surfaces relies on a hydrotris(indazolyl)borate scorpionate ligand ${ }^{[8]}$ functionalized with three thioether groups connected at the 6-position of the indazoles. This tripodal platform provides on one side strong anchoring on the metallic surface through the three S-Au bonds, and on the other side coordination to a ruthenium center which acts as a ball bearing, allowing the rotation of the upper ligand. This architecture has been used for the ruthenium-based molecular motor 1 (Figure 1), ${ }^{[9]}$ in which the rotating platform is a dissymmetric pentaarylcyclopentadienyl ligand, displaying four identical ferrocenyl-terminated arms and one shorter tolyl arm. Once deposited on $\mathrm{Au}(111)$, it has been shown using STM experiments that lateral manipulation of such molecular machine is possible at $77 \mathrm{~K}$ whilst molecular diffusion is totally frozen at $5 \mathrm{~K} \cdot{ }^{[9]}$ 

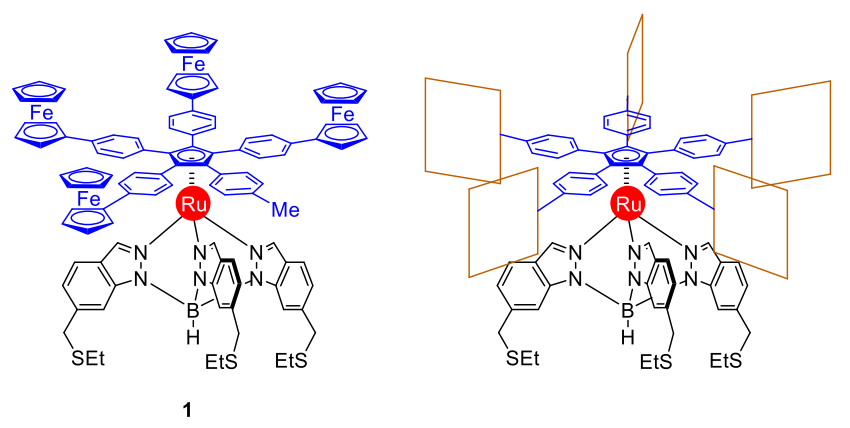

Figure 1. Structure of molecular motor 1 (left) and general design of ruthenium-based star-shaped molecular gears (right).

The hydrotris(indazolyl)borate ligand embedded in a ruthenium complex is therefore very attractive towards building a train of gears since it would allow the control and fine tuning of the intermolecular distances between gears at $77 \mathrm{~K}$ when the subsequent cooling to $5 \mathrm{~K}$ would lock the spatial arrangement of molecules during gearing experiments. In our targeted experiments, the STM tip will then be used both as a source of mechanical energy to induce the rotary motion of the first cogwheel by pushing on one of the teeth (Figure 2), and also as a probe to monitor a possible transmission of motion by imaging the final state.

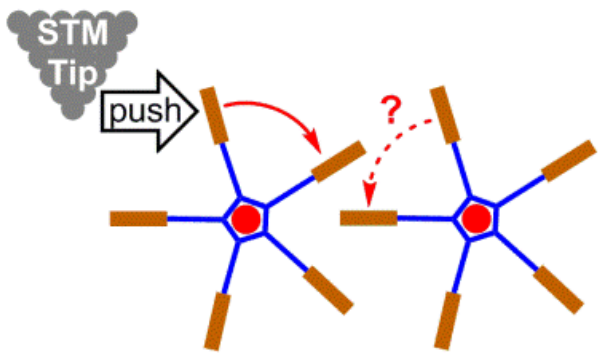

Figure 2. Expected gearing effect between two star-shaped ruthenium complexes in close proximity on a metallic surface, using a STM tip as a source of mechanical energy to rotate the first cogwheel.

For the design of the molecular gears involved in such on-surface experiments, the overall scaffold of the piano-stool ruthenium complex used in motor $\mathbf{1}$ was preserved but the structure of rotating platform was modified to favor the transmission of rotary motion (Figure 1, right). Indeed, a careful choice of the cyclopentadiene $(\mathrm{Cp})$ substituents is critical since intermolecular interactions of neighbouring teeth are key to successful gearing. Given the lack of precedence in gearing systems with a tunable intermolecular distance and with a cogwheel decoupled from the surface, it is difficult to anticipate the requirements for an effective transfer of rotary motion. It was thus decided to prepare a series of ruthenium-based molecular gears, incorporating five identical teeth of various lengths, shapes and structures. A divergent synthetic approach was devised, allowing for all of the symmetrical molecular gears to stem from the same precursor, namely the penta(p-bromophenyl)cyclopentadienyl ruthenium(II) complex 4a, incorporating the thioether-functionalized scorpionate ligand (Scheme 1). The optimized synthesis of pentaaryl bromide $4 \mathbf{a}$ has been recently reported ${ }^{[10]}$ and it has been shown that this key intermediate is prone to undergo five-fold Suzuki-Miyaura cross-coupling reactions. To expand the scope of crosscoupling reactions and access structurally different teeth in a straightforward manner, it appeared 
interesting to prepare the analogous pentaaryl iodide precursor $\mathbf{4 b}$ since aryl iodides are known to be more reactive in most cross-coupling reactions as compared to the corresponding aryl bromides. ${ }^{[1]}$

Herein we report the preparation of penta(p-iodophenyl)cyclopentadienyl ruthenium(II) complex $\mathbf{4 b}$, and the use of pentahalogenated ruthenium complexes $\mathbf{4 a}$ and $\mathbf{4 b}$ as key precursors of molecular gears through a divergent synthetic approach. We also present the synthesis and characterization of two families of molecular gears prototypes, respectively incorporating pseudo 1-dimensional aryl teeth or large planar 2-dimensional paddles of various nature.

\section{Results and Discussion}

The synthesis of the pentaaryl bromide precursor $\mathbf{4 a}$ was recently optimized, with a particular emphasis on the preparation of the thallium hydrotris(indazolyl)borate intermediate $\mathbf{3}$, functionalized with thioether anchoring groups (Scheme 1). ${ }^{[10]}$ The latter is now obtained in 4 steps from commerciallyavailable 3-amino-4-methylbenzoic acid, via a newly developed " $N$-deprotection / reductive sulfidation" one-pot sequence mediated by indium(III). The bromidodicarbonyl $\eta^{5}-1,2,3,4,5-\operatorname{penta}(p-$ bromophenyl)]cyclopentadienyl ruthenium(II) complex 2a stems from pentaphenylcyclopentadiene, that first undergoes bromination on the phenyl para-positions and on the $\mathrm{Cp}$ ring. The resulting hexabrominated compound then adds oxidatively onto the ruthenium $(0)$ cluster $\mathrm{Ru}_{3}(\mathrm{CO})_{12}$ to yield the ruthenium(II) complex 2a, bearing a $\eta^{5}$-cyclopentadienyl ligand surrounded by five $p$-bromophenyl arms. The final ligand exchange step in the presence of the thallium tripod $\mathbf{3}$ under microwave activation gives rise to the desired pentabrominated ruthenium complex $\mathbf{4 a}$, in $31 \%$ yield over the longest linear sequence (5 steps).

We recently reported an important reactivity difference between pentabromo- and pentaiodo-derivatives of the same family of ruthenium complexes bearing bare hydrotris(indazolyl)borate tripodal ligands (without $S$-based anchoring groups). ${ }^{[12]}$ While the pentabrominated derivative did not react with ethynylferrocene under Sonogashira conditions, it proved possible to achieve the five-fold Sonogashira coupling using the pentaiodinated precursor. It is inferred that the high electron density of the aryl bromide moieties within the ruthenium cyclopentadienyl complex might preclude the oxidative addition on the $\left[\mathrm{Pd}\left(\mathrm{PPh}_{3}\right)_{4}\right]$ catalyst in this reaction. This tendency is also confirmed by the restricted set of catalysts which are active even for Suzuki-Miyaura cross-couplings on the brominated precursor $\mathbf{4 a}$.

In our efforts to synthesize a variety of molecular gears, the implementation of various types of crosscoupling reactions will diversify the nature of the teeth, and/or the length of the linkers. The possibility to use either the brominated or iodinated precursors $\mathbf{4 a}$ and $\mathbf{4 b}$, respectively, will thus result in a higher flexibility in cross-coupling reactions.

\section{Preparation of pentaiodinated ruthenium complex $4 \mathrm{~b}$}

In order to prepare the pentaiodinated precursor $\mathbf{4 b}$, bearing five iodines instead of bromines at the phenyl para-positions, it was first envisioned to follow a synthetic route involving the iodinated analogue of complex 2a, which would be obtained by iodination of pentaphenylcyclopentadiene followed by oxidative addition onto ruthenium( 0 ). Unfortunately, in our hands, the iodination step proved unsuccessful. 

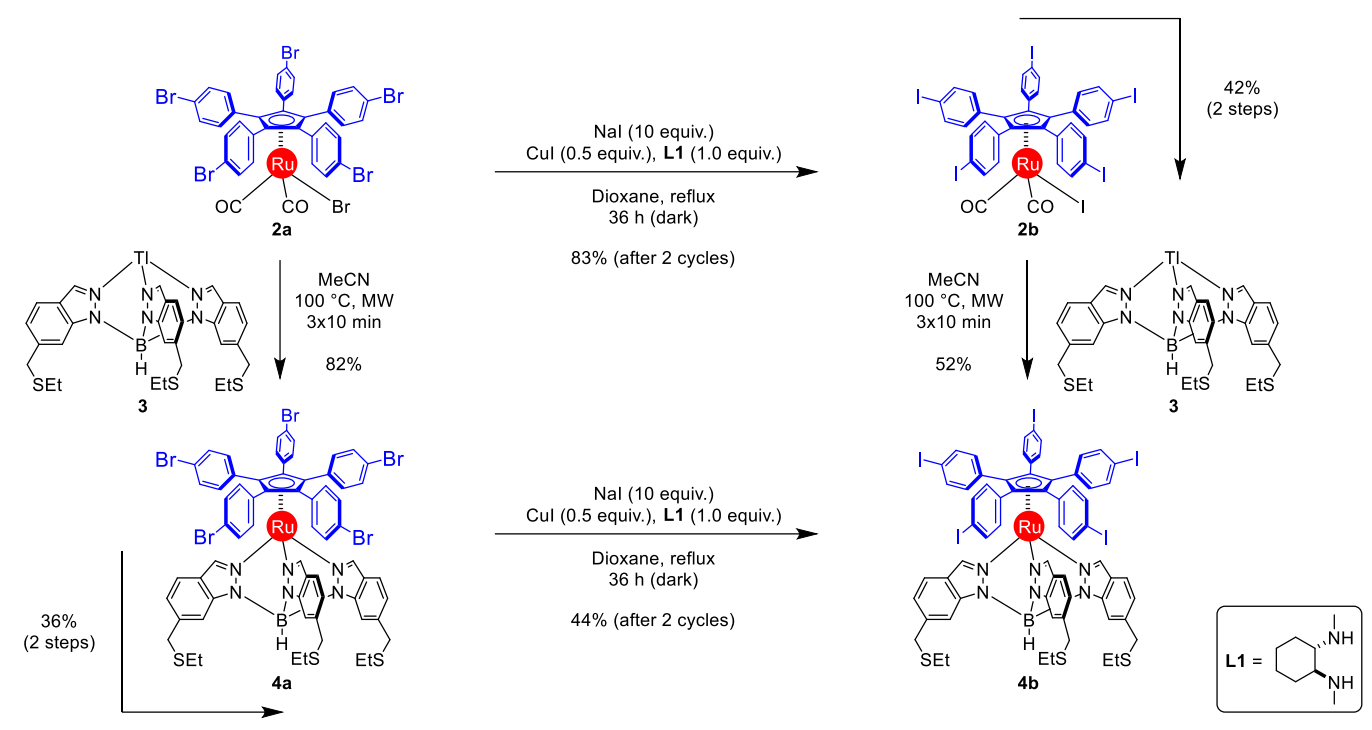

Scheme 1. Synthesis of pentaiodinated ruthenium complex $\mathbf{4 b}$ starting from precursor $2 \boldsymbol{a}$ via two different routes, each involving a Cu-catalyzed aromatic Finkelstein-type reaction and a ligand exchange step.

Alternatively, it was decided to introduce the iodine centers later in the synthetic sequence, via aromatic Finkelstein-type Br/I halogen exchange reactions. As reported earlier, ${ }^{[12]}$ hexabrominated ruthenium(II) complex 2a was treated with sodium iodide in the presence of copper iodide combined with a diamine ligand as the catalytic system to afford the corresponding hexaiodinated complex $\mathbf{2 b}$. This exchange process was initially observed by Klapars and Buchwald as a side reaction of copper-catalyzed $\mathrm{N}$ arylations, using aryl bromides as substrates and copper iodide as precatalyst. ${ }^{[13]}$ It is important to note that the $\mathrm{Br} / \mathrm{I}$ exchange process is an equilibrium and that the solubility difference between the halide salts has an impact on the position of this equilibrium. Under optimized conditions, the authors reported yields higher than $93 \%$ for the exchange in a variety of (hetero)aryl bromides. In our initial attempt to perform this reaction on ruthenium(II) complex 2a, the five-fold copper-catalyzed $\mathrm{Br} / \mathrm{I}$ exchange on the phenyl para-positions combined with a $\mathrm{Br} / \mathrm{I}$ exchange on the ruthenium center led to compound $\mathbf{2} \mathbf{b}$ in $45 \%$ yield. ${ }^{[12]}$ So as to reach a higher efficiency, the reaction conditions were optimized: complex $\mathbf{2 a}$ was refluxed in 1,4-dioxane in the presence of sodium iodide (2 equiv. / $\mathrm{Br}$ ), copper iodide (10 mol-\% / $\mathrm{Br})$ and $( \pm)-N, N$ '-dimethyl-trans-cyclohexane-1,2-diamine L1 (20 mol-\% / Br) (Scheme 1). After $36 \mathrm{~h}$, the ${ }^{1} \mathrm{H}$ NMR spectrum of the crude mixture showed a very clean $\mathrm{Br} / \mathrm{I}$ exchange process but only a partial overall conversion of the bromophenyl to iodophenyl moieties (see Fig. S1 in the Supporting Information). Indeed, following a fast substitution of the bromides located on the ruthenium center, the crude material composed of a mixture of mono- to penta( $p$-iodophenyl) derivatives, indicating that the copper-catalyzed $\mathrm{Br} / \mathrm{I}$ exchange on the aromatic positions was not quantitative. After removal of the inorganic residues by passing the mixture of partially and totally iodinated compounds through a plug of silica, the obtained mixture was resubmitted to the same reaction conditions in order to drive the equilibrium towards aryl iodides. Complete $\mathrm{Br} / \mathrm{I}$ exchange was observed after another $36 \mathrm{~h}$ (see Fig. S1 in the Supporting Information) and the desired iodinated complex $\mathbf{2 b}$ isolated in $83 \%$ yield. Ligand exchange on complex $\mathbf{2 b}$ in the presence of the thallium hydrotris(indazolyl)borate $\mathbf{3}$ in acetonitrile under microwave irradiation afforded the desired pentaiodinated precursor $\mathbf{4 b}$ in $52 \%$ yield.

Interestingly, with the new optimized conditions for the copper-catalyzed $\mathrm{Br} / \mathrm{I}$ exchange, the pentabrominated precursor $\mathbf{4 a}$ incorporating the thioether-functionalized scorpionate ligand undergoes 
halogen exchange in spite of the steric hindrance to give its iodinated counterpart $\mathbf{4 b}$ in $44 \%$ yield (85\% per $\mathrm{Br} / \mathrm{I}$ exchange). It must be noted that a previous attempt of $\mathrm{Br} / \mathrm{I}$ exchange on the analogue complex lacking thioether functional groups under non-optimized conditions led to a complex mixture of partially substituted products. ${ }^{[12]}$ These new exchange conditions highlight the reactivity of the pentabrominated precursor $\mathbf{4 a}$ in copper catalysis, in spite of the functional complexity and steric hindrance within this ruthenium complex.

The pentaiodinated key intermediate $\mathbf{4 b}$ can be obtained from ruthenium complex $\mathbf{2 a}$ by two routes, involving first the halogen exchange step followed by coordination of the tripodal ligand, or the reverse sequence, in comparable overall yields of $42 \%$ and $36 \%$, respectively. Our previous work on the improvement of the synthesis of thallium hydrotris(indazolyl) borate $\mathbf{3}$ combined with our efforts to optimize the five-fold aromatic Finkelstein-type $\mathrm{Br} / \mathrm{I}$ exchange allowed the preparation of the desired pentabrominated and pentaiodinated ruthenium complexes $\mathbf{4 a}$ and $\mathbf{4 b}$, in $31 \%$ and $19 \%$ overall yields on the longest linear sequence (5 steps), respectively. Both complexes were further engaged in multiple cross-coupling reactions according to a divergent approach, to vary the structure and the length of the teeth in molecular gears prototypes.

\section{Prototypes of molecular gears with pseudo 1D-teeth}

A first family of molecular gears prototypes was prepared, bearing five substituted 4,4'-biphenyl groups connected to the central cyclopentadienyl ring. The pentaaryl bromide precursor $\mathbf{4 a}$ was engaged in Suzuki-Miyaura cross-coupling reactions with appropriately substituted phenylboronic acids (Scheme 2). This type of five-fold aryl-aryl cross-coupling reaction was already exploited in our group for the synthesis of ruthenium-based molecular motors, incorporating ester- or thioether-functionalized scorpionate ligands. ${ }^{[8,10]}$ Under optimized conditions, pentaaryl bromide 4a was treated with a large excess of 4-tert-butylphenylboronic acid (4 equiv. / Br) in carefully degassed anhydrous toluene, using palladium diacetate $(6 \mathrm{~mol}-\% / \mathrm{Br})$ with $\mathrm{SPhos}(12 \mathrm{~mol}-\% / \mathrm{Br})$ as catalytic system and potassium phosphate (2 equiv./Br) as base. The resulting mixture was refluxed for $24 \mathrm{~h}$ and the same amounts of catalyst and reagents were added again. After another $24 \mathrm{~h}$ at reflux, the desired product 5 resulting from five consecutive Suzuki-Miyaura couplings was obtained in $82 \%$ yield.
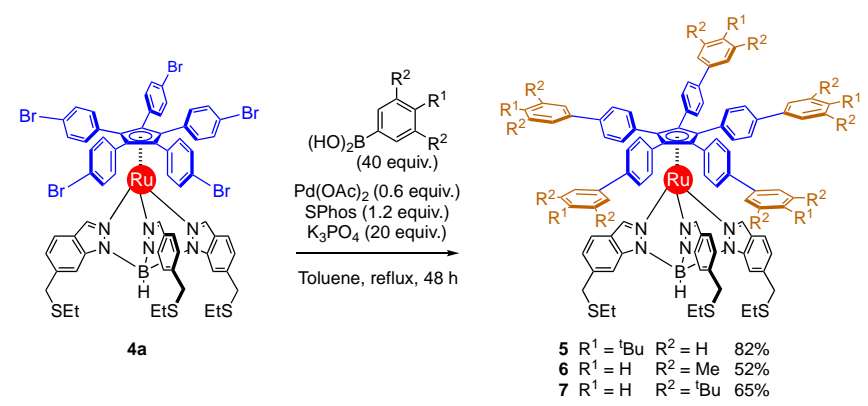

Scheme 2. Five-fold Suzuki-Miyaura cross-coupling reactions of pentabrominated precursor 4 a to yield molecular gears prototypes 5-7 incorporating pseudo-1D teeth.

Compound 5 was fully characterized by ${ }^{1} \mathrm{H}$ and ${ }^{13} \mathrm{C}$ NMR spectroscopy, as well as mass spectrometry, thereby confirming the incorporation of the five 4-tert-butylphenyl peripheral groups. In particular, ${ }^{1} \mathrm{H}$ NMR clearly shows two AA'BB' patterns integrating each for 20 protons and corresponding to the five 
4,4'-biphenyl systems surrounding the central cyclopentadienyl ring and substituted by a tert-butyl group in the outer para-position. Moreover, careful analysis of the spectra revealed that the three indazole moieties are chemically equivalent, which shows that this molecular gear prototype undergoes free rotation at room temperature.

It was possible to grow crystals of compound $\mathbf{5}$ suitable for X-ray diffraction by slow diffusion of methanol into a solution of complex $\mathbf{5}$ in toluene. Molecular views of 5, shown in Figure 3, confirmed the piano-stool structure of the ruthenium complex, with the hydrotris(indazolyl)borate ligand binding in a facial tripodal $\kappa^{3}-N, N^{\prime}, N$ ' mode. The average distance between the three coordinating nitrogen atoms and the ruthenium center is $2.15 \AA$, while the distance between the cyclopentadienyl ligand and the ruthenium center is $1.80 \AA$. These values are fully consistent with those obtained previously for parent ruthenium complexes. ${ }^{[12]}$ Strikingly, all the 4,4'-biphenyl teeth are located out of the central Cp mean plane, pointing away from the hydrotris(indazolyl)borate ligand, with the $\mathrm{C}_{\mathrm{ipso}}$ of the inner phenylene groups undergoing deviation of $0.10 \AA$ to $0.36 \AA$ compared to the $\mathrm{Cp}$ mean plane (see Supporting Information). This effect can be ascribed to steric hindrance within the ruthenium complex.

a.

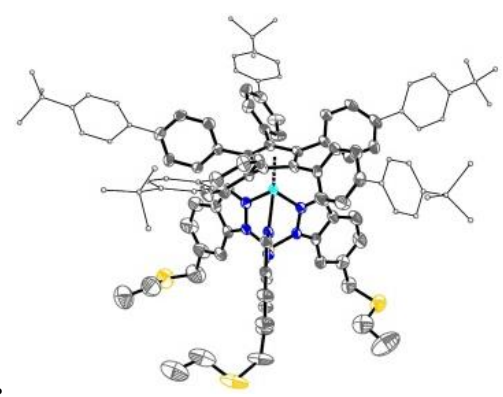

b.

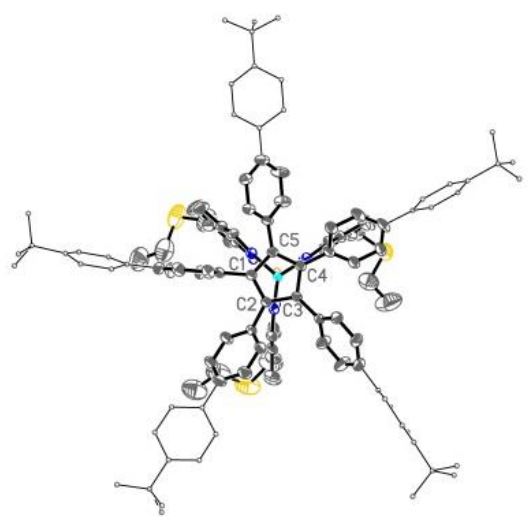

Figure 3. Side view (a) and top view (b) of the molecular structure of ruthenium complex 5. Thermal ellipsoids drawn at $50 \%$ probability, hydrogen atoms, solvent molecules and disordered atoms are omitted for clarity.

For such piano-stool systems combining a $C_{3^{-}}$and a $C_{5}$-symmetric ligand, a staggered and an eclipsed conformation are observed with, respectively, minimal dihedral angles of $12^{\circ}$ and $0^{\circ}$ between one $\mathrm{Cp}$ substituent and the closest indazole ring. ${ }^{[12]}$ With a torsion angle of $9^{\circ}$ between the biphenyl tooth located on cyclopentadienyl $\mathrm{C}_{4}$ and the indazole core underneath, it appears that complex $\mathbf{5}$ crystallizes in a close to staggered conformation. The five $\mathrm{Cp}$ biphenyl substituents are thus inequivalent, as confirmed by the different tilt angles of their inner phenylene units. Indeed, the phenylene group connected to $\mathrm{C}_{1}$ is almost perpendicular to the $\mathrm{Cp}$ plane $\left(87^{\circ}\right)$ while the one on $\mathrm{C}_{4}$ exhibits the smallest angle of $39^{\circ}$, due to its interaction with the indazole core. The three remaining phenylenes have tilting angles of $51^{\circ}$ to $59^{\circ}$. Finally, as expected, the 4,4'-biphenyl systems are all twisted with the magnitude of the torsion between consecutive para-phenylene units is variable, with values ranging from $16^{\circ}$ to $44^{\circ}$ in the solid state.

The molecular structure of complex $\mathbf{5}$ highlights the bifunctional role of the scorpionate ligand, with one face dedicated to ruthenium coordination while the other one will allow on-surface adsorption (Figure 3a). As anticipated in the design, this ligand will act both as anchor and rotation axle. The star-shaped 
cogwheel, based on the pentaaryl cyclopentadienyl ligand, will in turn be lifted up from the surface and allow intermeshing of the teeth of neighbouring molecules (Figure $3 b$ ).

To increase the steric hindrance of the teeth, 3,5-disubstituted phenylboronic acids were next selected and following the same approach, the analogues $\mathbf{6}$ and $\mathbf{7}$ carrying methyl or tert-butyl groups on the peripheral meta positions were obtained in $52 \%$ and $65 \%$ yield, respectively (Scheme 2). Even if the efficiency of the five-fold Suzuki-Miyaura couplings with 3,5-disubstituted phenylboronic acids seems substantially lower than with 4-tert-butylphenylboronic acid, it must be noted that the yield per coupling remains in the same range $(96 \%, 88 \%$ and $92 \%$ for $\mathbf{5 , 6}$ and $\mathbf{7}$, respectively).

A first family of molecular gears with substituted 4,4'-biphenyl moieties as teeth was thus obtained via multiple aryl-aryl cross-coupling reactions, starting from the same pentaaryl bromide precursor $\mathbf{4 a}$. These three prototypes exhibit a similar size, with a diameter in the 2-2.5 nm range, and incorporate pseudo one-dimensional teeth. These first prototypes will be studied by STM on Au(111) by physicists in the near future. The deposition conditions as well as the possibility to assemble trains of gears by STM tip lateral manipulation will be assessed, and the first investigations of intermolecular transfer of rotary motion will be performed. However, preliminary theoretical studies suggest a possible vertical deformation of the teeth due to their relative flexibility, thus preventing gearing.

To avoid potential gear slippage and favor mechanical transmission of motion, it was envisioned to increase the size of the teeth, moving from pseudo 1D-biphenyl teeth to larger 2D paddles. Several appropriate candidates such as carbazoles, BODIPYs and porphyrins were identified to possibly act as paddles, since they display flat structures and large areas. Importantly, the incorporation of such bidimensional fragments in molecular gears prototypes might lead to solubility issues during the synthesis and to enhanced $\pi$-stacking between neighbouring molecules on surface, which could be detrimental for gearing processes. Bulky alkyl groups were thus systematically integrated in the design of the paddles.

\section{Prototypes of molecular gears with 2D-paddles}

A carbazole core carrying two tert-butyl groups in the 3,6-positions was first chosen to act as a 2Dpaddle, since the diameter of the resulting molecular gear would be similar to the diameter of complexes 5-7. This would allow a direct comparison of the influence of the structure of the teeth, while keeping their length constant.

A first attempt of palladium-catalyzed Buchwald-Hartwig reaction ${ }^{[14]}$ between pentabrominated precursor 4a and commercially-available 3,6-di-tert-butyl-9H-carbazole under standard coupling conditions failed to afford the expected product. However, we remembered that the copper-catalyzed Finkelstein-type halogen exchange in aryl halides had been developed by exploiting a side-reaction observed during copper-catalyzed $N$-arylation reactions, ${ }^{[15]}$ as mentioned by Klapars and Buchwald. ${ }^{[13]}$ Given the reactivity of the pentaaryl bromide precursor $\mathbf{4 a}$ under $\mathrm{Br} / \mathrm{I}$ exchange conditions, it was envisioned to perform direct functionalization under copper catalysis using carbazole as the nucleophile.

Precursor 4a was thus treated with 3,6-di-tert-butyl-9H-carbazole (2 equiv./Br) in the presence of potassium phosphate as base, combined with copper iodide and ( \pm )-trans-cyclohexane-1,2-diamine $\mathbf{L} \mathbf{2}$ as the catalytic system (Scheme 3). After 2 days in refluxing 1,4-dioxane, the pentasubstituted gear 8 was obtained in $19 \%$ yield. It has been shown that such copper-catalyzed $N$-arylation reactions are more efficient using aryl iodides rather than bromides. ${ }^{[16]}$ The same reaction was subsequently tested with the iodinated precursor $\mathbf{4 b}$ and the product $\mathbf{8}$ was isolated in a higher yield of $28 \%$, corresponding to $78 \%$ 
per C-N coupling. Mass spectrometry and NMR spectroscopy confirmed the presence of five carbazole units. The aromatic region of the ${ }^{1} \mathrm{H}$ NMR spectrum displays the 30 protons corresponding to the five 3,6-disubstituted carbazole moieties, as compared to 20 protons for the AA'BB' pattern of the five phenylene groups surrounding the $\mathrm{Cp}$ ring, and the 12 characteristic protons of the indazole cores. Free rotation at room temperature was still observed, in spite of the enhanced steric hindrance of the teeth.
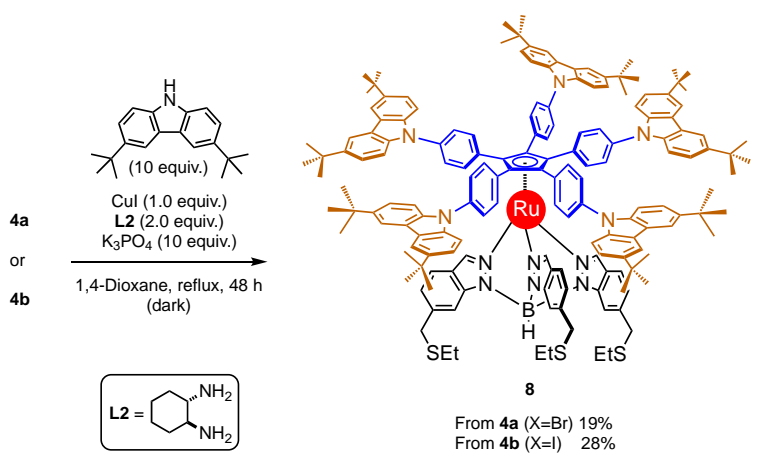

Scheme 3. Five-fold Cu-catalyzed N-arylation of precursors $\mathbf{4 a}$ and $\mathbf{4 b}$ to yield molecular gear prototype 8 incorporating carbazole-based paddles.

To increase the diameter of the cogwheel and vary the nature of the paddles, a BODIPY fragment was selected to prepare the next prototype of molecular gear, with a 4,4'-biphenyl linkage to the central cyclopentadienyl ring. For enhanced stability and solubility, the pyrrole cores were peralkylated with methyl and ethyl groups. The appropriate BODIPY-substituted phenyl boronic acid pinacol ester 9 was prepared $^{[17]}$ and subsequently engaged in a Suzuki-Miyaura cross-coupling with the pentaaryl bromide precursor 4a (Scheme 4, right). Under the conditions previously used for the synthesis of bis-aryl gears 5-7, the desired product 10 was detected by mass spectrometry analysis of the crude mixture, along with by-products of mono-, di-, tri- and tetrafunctionalization. Unfortunately, only traces amounts of compound $\mathbf{1 0}$ were obtained after purification. A biphasic solvent system combining toluene/ethanol/water (2:2:1) ${ }^{[18]}$ was then employed leading to an increase of the reaction efficiency, and the desired penta-BODIPY product $\mathbf{1 0}$ was isolated in $36 \%$ yield. This new complex was characterized by mass spectrometry as well as ${ }^{1} \mathrm{H},{ }^{13} \mathrm{C},{ }^{11} \mathrm{~B}$ and ${ }^{19} \mathrm{~F}$ NMR spectroscopy. On the ${ }^{1} \mathrm{H}$ NMR spectrum, integration of the two AA'BB' systems corresponding to the 4,4'-biphenyl linkers and of the methyl and ethyl groups located on the pyrroles as compared to protons belonging to the equivalent indazole rings show that five BODIPY moieties have indeed been coupled. In the ${ }^{19} \mathrm{~F}$ NMR, a quadruplet is observed at $-145.7 \mathrm{ppm}$ with a coupling constant $J\left({ }^{11} \mathrm{~B}-{ }^{19} \mathrm{~F}\right)$ of $33.3 \mathrm{~Hz}$, proving the coupling with the neighbouring boron atom. The same pattern was observed in the BODIPY-substituted phenylboronic acid pinacol ester precursor 9, indicating that both fluorine atoms are equivalent on each of the BODIPY teeth, which are themselves all equivalent, due to combined free rotation along the $\mathrm{Cp}-\mathrm{Ru}-\mathrm{B}$ axis and each 4,4'-biphenyl axis. This is further confirmed by ${ }^{11} \mathrm{~B}$ NMR, exhibiting one triplet at $0.7 \mathrm{ppm}$ with a coupling constant $J\left({ }^{11} \mathrm{~B}-{ }^{19} \mathrm{~F}\right)$ of $33.3 \mathrm{~Hz}$. 

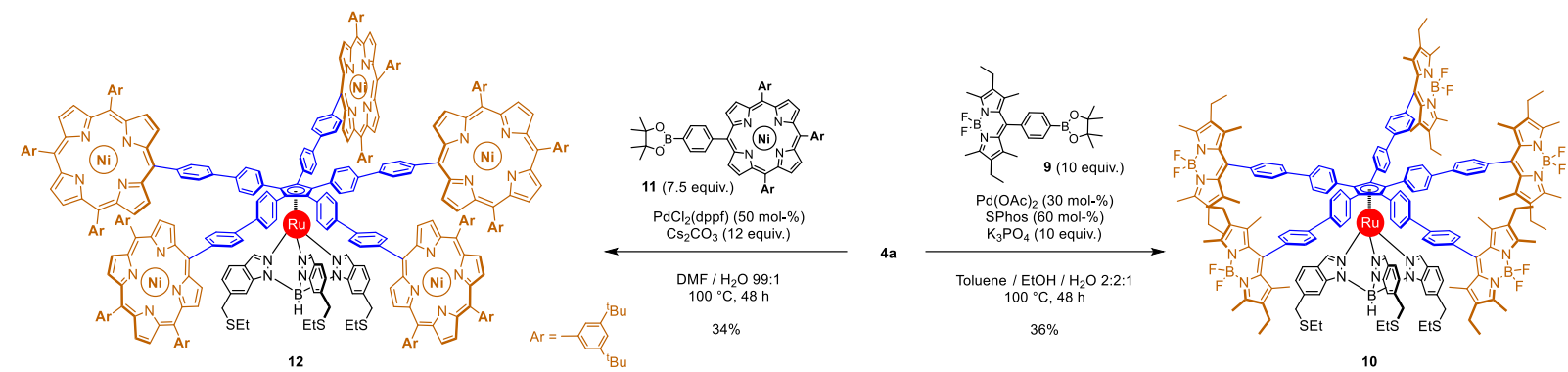

Scheme 4. Five-fold Suzuki-Miyaura cross-coupling reactions of pentabrominated precursor 4 a to yield molecular gears prototypes 10 and 12, incorporating BODIPY- and porphyrin-based paddles, respectively.

A rigid planar porphyrin scaffold was also used for the next generation of paddles to further increase the size and the surface of the teeth. The design of these paddles involves 3,5-di-tert-butylphenyl groups at three of the porphyrin meso positions, for higher stability, higher solubility and limited $\pi$-stacking. Moreover, to avoid any undesired metallation of the porphyrins once deposited on the metallic surface ${ }^{[19]}$ we planned to use metallated porphyrins with nickel(II) selected as the metallic center. Using this core structure for paddles, it is possible to modulate the diameter of the gears by variation of the nature of the linker between the cyclopentadienyl platform and the porphyrin. Indeed, as mentioned earlier, Suzuki-Miyaura cross-coupling with a phenyl boronic acid derivative carrying the porphyrin core will give rise to a gear prototype with 4,4'-biphenyl linkers, whereas a Sonogashira cross-coupling will afford the corresponding extended gear with longer phenylethynylphenyl linkers.

The $A_{3} B$-type porphyrinic coupling precursor 11 was synthesized following Lindsey's method ${ }^{[20]}$ under statistical conditions (Scheme 4, left). Stoichiometric amounts of pyrrole, 3,5-di-tert-butylbenzaldehyde and 4-(tetramethyl-1,3,2-dioxaborolan-2-yl)benzaldehyde were treated with $\mathrm{BF}_{3} \cdot \mathrm{OEt}_{2}$ in chloroform, and subsequent oxidation with chloranil yielded the corresponding $A_{3} B$ porphyrin after purification. Metallation was then performed in the presence of excess nickel(II) acetylacetonate and the desired nickel porphyrin 11 was isolated in $8 \%$ overall yield over two steps. The same strategy was followed for the synthesis of the second porphyrin 13, carrying an ethynylphenyl group at one meso position (Scheme 5). The reaction of pyrrole, 3,5-di-tert-butylbenzaldehyde and 4[(trimethylsilyl)ethynyl]benzaldehyde $\mathbf{1 5}$ under Lindsey's conditions, followed by alkyne deprotection and subsequent metallation gave the desired porphyrinic precursor $\mathbf{1 3}$ in 7\% yield over 3 steps.

With both precursors in hand, the palladium-catalyzed cross-coupling reactions were tackled. The Suzuki-Miyaura reaction of brominated precursor $\mathbf{4 a}$ with $\mathrm{A}_{3} \mathrm{~B}$ porphyrin-derived boronic acid pinacol ester 11 required some optimization. The desired gear 12 carrying five porphyrin paddles was isolated in $34 \%$ yield after $48 \mathrm{~h}$ at $100{ }^{\circ} \mathrm{C}$ in a DMF/water system (99:1), using only 7.5 equiv. of boronic ester 11 (i.e. 1.5 equiv./aryl bromide) in the presence of $\mathrm{Pd}(\mathrm{dppf}) \mathrm{Cl}_{2}(10 \mathrm{~mol}-\% / \mathrm{Br})$ as catalyst and excess cesium carbonate as base (Scheme 4, left). In contrast, the pentaiodinated precursor $\mathbf{4 b}$ was selected for the Sonogashira reaction since aryl iodides are known to react under very mild conditions in such couplings. ${ }^{[1]}$ Pentaaryl iodide $\mathbf{4 b}$ was thus reacted with alkynylporphyrin $\mathbf{1 3}$ in the presence of $\mathrm{Pd}\left(\mathrm{PPh}_{3}\right)_{2} \mathrm{Cl}_{2}(10 \mathrm{~mol}-\% / \mathrm{I})$ and $\mathrm{CuI}(6 \mathrm{~mol} \% / \mathrm{I})$ as catalysts in triethylamine (Scheme 5). After $24 \mathrm{~h}$ at $45{ }^{\circ} \mathrm{C}$, product 14 resulting from five consecutive $\mathrm{C}-\mathrm{C}$ couplings was isolated in $62 \%$ yield. 


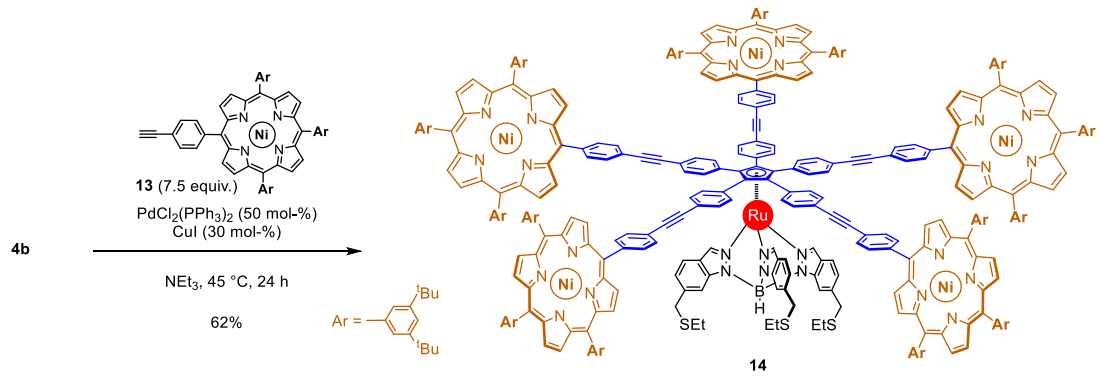

Scheme 5. Five-fold Sonogashira cross-coupling reaction of pentaiodinated precursor $\mathbf{4 b}$ to yield molecular gear prototype 14, incorporating extended porphyrin-based paddles.

Both complexes were fully characterized by mass spectrometry as well as NMR and UV-visible spectroscopies. The lighter compound 12, incorporating 4,4'-biphenyl linkers, has a molar weight of 6162 g.mol ${ }^{-1}$. This consists to a total 870 atoms, among which 405 carbon atoms. MALDI-TOF mass spectrometry was thus run on both samples and confirmed the penta-functionalization of the cyclopentadienyl ruthenium(II) core with nickel(II) porphyrins. Moreover, the presence of $40 \beta$-pyrrolic protons and 40 phenylene protons (in AA'BB' patterns) compared to a total of 12 protons on the indazole cores corroborated the expected structures for $\mathbf{1 2}$ and 14. Due to the high degree of symmetry within these structures and to free rotation at room temperature, the ${ }^{1} \mathrm{H}$ and ${ }^{13} \mathrm{C}$ NMR spectra could be fully assigned. Interestingly, two distinct sets of signals corresponding to the 3,5-di-tert-butylphenyl groups located on the 5,10,15 meso positions of the porphyrins were detected. Indeed, the ten 3,5-di-tertbutylphenyl substituents on the 5 and 15 meso positions are all equivalent, and can be distinguished from the five aryl groups located on the outer meso positions of the trans- $\mathrm{A}_{2} \mathrm{BC}$ porphyrins. It is important to note that this is observed for both complexes $\mathbf{1 2}$ and $\mathbf{1 4}$, meaning that the porphyrins carried by the smaller gear prototype $\mathbf{1 2}$ still undergo unrestricted rotation around the 4,4'-biphenyl axes, in addition to the free rotation around the $\mathrm{Cp}-\mathrm{Ru}-\mathrm{B}$ axis. Finally, a comparison of the UV-visible spectra of porphyrin precursors $\mathbf{1 1}$ and $\mathbf{1 3}$ with those of the corresponding penta-porphyrin complexes $\mathbf{1 2}$ and 14, respectively, showed that no shift of the Soret and Q bands occurs as a consequence of the porphyrins' connection. Incidentally, the molar extinction coefficients $\varepsilon$ associated to these bands are proportional to the number of porphyrin cores in the studied molecular species, revealing an additivity of the absorption properties of the chromophores in ruthenium complexes $\mathbf{1 2}$ and $\mathbf{1 4 .}$

\section{Conclusions}

In this work, a series of prototype star-shaped molecular gears were synthesized with the aim of assembling them into trains of gears on surface and ultimately achieving controlled intermolecular gearing motion. The design of such rotary molecular machines is based on a piano-stool architecture, with the ruthenium center acting as ball bearing between the pentaarylcyclopentadienyl cogwheel and a hydrotris(indazolyl) borate ligand as rotation axle. The latter is specifically functionalized to provide tight anchoring on metallic surfaces, thus preventing diffusion of the molecular gears at $5 \mathrm{~K}$ and offering control over intermolecular distances in linear assemblies.

Given the lack of precedence in intermolecular transfer of motion between complexes, the star-shaped cogwheel were equipped with various types of teeth, ranging from substituted 4,4'-biphenyl groups to rigid nickel(II) porphyrins, in order to study the influence of their structure on intermeshing and gearing phenomena. Two distinct families of molecular gear prototypes were prepared, incorporating five 
identical pseudo 1-dimensional aryl teeth or large planar 2-dimensional paddles of various natures and lengths.

To efficiently reach such structural diversity, a divergent synthetic approach was followed starting from a key precursor, penta( $p$-bromophenyl)cyclopentadienyl ruthenium(II) complex and implementing various types of transition metal-catalyzed cross-couplings. Five-fold Suzuki-Miyaura reactions with different partners such as substituted phenylboronic acids, as well as BODIPY- and porphyrin-derived boronic esters gave a series of molecular gear prototypes featuring teeth of increasing size and length. To expand the scope of cross-coupling reactions, the pentaaryl iodide counterpart of the key precursor was prepared via an aromatic Finkelstein-type $\mathrm{Br} / \mathrm{I}$ exchange. Subsequently, two extra gears incorporating carbazoles and porphyrins as 2D-paddles were obtained by copper-catalyzed $N$-arylation and Sonogashira coupling, respectively.

All these compounds were fully characterized and were shown to undergo free rotation at room temperature, even in the case of the most sterically-hindered penta-porphyrin derivatives. Additionally, an X-ray crystal structure of the penta( $p$-tert-butylbiphenyl)cyclopentadienyl ruthenium complex was obtained, thus allowing validation of the expected 3D structural features of the molecular gears in anticipation of their on-surface study by STM.

In the absence of time-resolution, controlled motion at the single molecule scale is evidenced by comparison of STM images acquired before and after the stimulus. It thus appears highly desirable to include a dissymmetry element in cogwheels, in order to precisely monitor by STM a possible gearing effect within trains of gears. The synthesis of such dissymmetric molecular gears, including one tagged tooth, is currently underway.

\section{Experimental Section}

\section{General methods:}

All commercially available chemicals were of reagent grade and were used without further purification. Anhydrous 1,2-dichloroethane, anhydrous THF, anhydrous acetonitrile, anhydrous toluene, anhydrous 1,4-dioxane, anhydrous $N, N$-dimethylformamide, methanol, chloroform, anhydrous triethylamine, 2,3dichloro-5,6-dicyano- $p$-benzoquinone (DDQ), 4-bromobenzaldehyde, chloranil, 3,5-bis(tertbutyl)benzaldehyde, 3,5-dimethylphenylboronic acid , 3,5-bis(tert-butylphenyl)boronic acid, bis(triphenylphosphine)palladium(II) dichloride, [1,1' -bis(diphenylphosphino)ferrocene $]$ dichloro palladium(II), potassium phosphate, nickel(II) acetylacetonate, sodium iodide and ( \pm )-trans- $N, N^{\prime}-$ dimethylcyclohexane-1,2-diamine were purchased from Aldrich. Boron trifluoride diethyl etherate, pyrrole, 4-tert-butylphenylboronic acid, potassium carbonate, copper iodide and $\left[1,1^{\prime}\right.$ bis(diphenylphosphino) ferrocene]dichloropalladium(II) (dichloromethane adduct) were purchased from Acros. 3,6-Di-tert-butyl-9H-carbazole, 4-(4,4,5,5-tetramethyl-1,3,2-dioxaborolan-2yl)benzaldehyde, and palladium(II) acetate were purchased from ABCR. 2,4-Dimethyl-3-ethylpyrrole, trifluoroacetic acid, 2-dicyclohexylphosphino-2'-6'-dimethoxybiphenyl (SPhos) and ( \pm )-trans-1,2diaminocyclohexane from TCI. Compounds $\mathbf{2 a}, \mathbf{3}$ and $\mathbf{4 a}$ were synthesized according to the procedures recently reported by our group. ${ }^{[10]}$ All reactions were carried out using standard Schlenk techniques under an argon atmosphere. Column chromatography was carried out on 230-400 mesh silica gel (Aldrich) unless otherwise stated. Microwave reactions were carried out using CEM Discover LabMate. Thin layer chromatography (TLC) was performed on pre-coated aluminum-backed silica gel $60 \mathrm{UV}_{254}$ plates (Macherey-Nagel) with visualization effected using ultraviolet irradiation $(\lambda=254,366 \mathrm{~nm})$. NMR, IR and mass spectra were recorded by the appropriate services of the Toulouse Institute of 
Chemistry (ICT - FR2599). ${ }^{1} \mathrm{H}$ and ${ }^{13} \mathrm{C}$ NMR spectra were recorded on Bruker Avance III HD $500 \mathrm{MHz}$ (cryoprobe Prodigy 5mm BBO, $1 \mathrm{H}$ ATMA), Avance $500 \mathrm{MHz}$ (cryoprobe $5 \mathrm{~mm}{ }^{1} \mathrm{H},{ }^{13} \mathrm{C}$ ), and Avance $300 \mathrm{MHz}$ (probe $5 \mathrm{~mm}$ BBO BB-1H Z-GRD) spectrometers. ${ }^{11} \mathrm{~B}$ and ${ }^{19} \mathrm{~F}$ NMR spectra were recorded on an Avance $300 \mathrm{MHz}$ (probe $5 \mathrm{~mm}$ BBO BB-1H Z-GRD) spectrometer. Residual solvent signals were used as internal reference for ${ }^{1} \mathrm{H}$ and ${ }^{13} \mathrm{C}$ NMR, and ${ }^{11} \mathrm{~B}$ and ${ }^{19} \mathrm{~F}$ NMR spectra were referenced according to the solvent. Chemical shifts $(\delta)$ are reported in ppm. Coupling constants $(J)$ are given in $\mathrm{Hz}$ and the following abbreviations have been used to describe the signals: singlet (s); broad singlet (br. s); doublet (d); triplet (t); quadruplet (q); quintuplet (quint); multiplet (m). Full assignments of ${ }^{1} \mathrm{H}$ and ${ }^{13} \mathrm{C}$ NMR spectra were made with the assistance of COSY, HMBC, and HSQC spectra when necessary. The numbering system used for the assignment of signals in new compounds is provided in the supporting information document, along with the corresponding spectra. IR spectra were recorded with a Nicolet 6700 FTIR-ATR. Only selected characteristic peaks are recorded. High-resolution mass spectra (HRMS) were performed with a Waters GCT Premier spectrometer for desorption chemical ionization $\left(\mathrm{DCI} / \mathrm{CH}_{4}\right.$ ), with a Waters Xevo G2 QTof spectrometer for electrospray ionization (ESI), and with a Waters MALDI micro MX spectrometer for matrix-assisted laser desorption ionization (MALDI) (matrix: trans-2-[3-(4-tert-butylphenyl)-2-methyl-2-propenylidene]malononitrile DTCB; $\lambda=337 \mathrm{~nm}$ ). UV/Vis spectra were recorded with a Shimadzu UV-26000 spectrometer ( $\mathrm{sh}=$ shoulder, $\varepsilon\left[\mathrm{mol}^{-1} \mathrm{dm}^{3} \mathrm{~cm}^{-}\right.$ ${ }^{1}$ ] is reported in parentheses). Cyclic voltammograms were obtained with an Autolab system (PGSTAT100) in $\mathrm{CH}_{2} \mathrm{Cl}_{2}\left(0.1 \mathrm{M}\right.$ tetrabutylammonium hexafluorophosphate $n \mathrm{Bu}_{4} \mathrm{NPF}_{6}$ as the supporting electrolyte, scan rate of $0.1 \mathrm{~V} \mathrm{~s}^{-1}$ ) at $25^{\circ} \mathrm{C}$. A three-electrode cell was used comprised of a 1 mm platinum disk working electrode, a platinum wire auxiliary electrode, and an aqueous SCE reference electrode. Crystallographic data for compound 5 were collected at 193(2) K on a Bruker-AXS Kappa APEX II Quazar diffractometer equipped with a $30 \mathrm{~W}$ air-cooled microfocus source using Mo $\mathrm{K}_{\alpha}$ radiation $(\lambda=0.71073 \AA$ ). Phi- and omega-scans were used. Space group was determined on the basis of systematic absences and intensity statistics. Semi-empirical absorption correction was employed. ${ }^{[22]}$ The structure was solved using an intrinsic phasing method (SHELXT), ${ }^{[23]}$ and refined using the leastsquares method on $F^{2} \cdot{ }^{[24]}$ All non-H atoms were refined with anisotropic displacement parameters. Hydrogen atoms were refined isotropically at calculated positions using a riding model with their isotropic displacement parameters constrained to be equal to 1.5 times the equivalent isotropic displacement parameters of their pivot atoms for terminal $\mathrm{sp}^{3}$ carbon and 1.2 times for all other carbon atoms. Hydrogen on Boron atom was located by difference Fourier map.

\section{Iodo $\eta^{5}$-1,2,3,4,5-penta-( $p$-iodophenyl)cyclopentadienyl dicarbonyl ruthenium(II) (2b):}

In a dry Schlenk tube were successively added a magnetic stirrer bar, NaI (700 mg, $4.67 \mathrm{mmol}, 10$ equiv.), bromo $\eta^{5}$-1,2,3,4,5-penta-(4-bromophenyl)cyclopentadienyl dicarbonyl ruthenium (II) $2 \mathbf{a}$ (500 $\mathrm{mg}, 0.46 \mathrm{mmol}, 1.0$ equiv.) and $\mathrm{CuI}(44 \mathrm{mg}, 0.23 \mathrm{mmol}, 0.5$ equiv.). It was briefly evacuated and backfilled with argon. Degassed dry 1,4-dioxane (3 mL) and ( \pm )-trans- $N, N$-dimethylcyclohexane-1,2diamine $(75 \mu \mathrm{L}, 0.48 \mathrm{mmol}, 1.02$ equiv.) were then added under argon. The reaction mixture was heated at $110{ }^{\circ} \mathrm{C}$ for $36 \mathrm{~h}$ in the dark. It was then allowed to cool down to room temperature, filtered through a celite pad (using $\mathrm{CH}_{2} \mathrm{Cl}_{2}$ ) and the solvent was removed under vacuum. The crude mixture was purified by column chromatography $\left(\mathrm{SiO}_{2}, \mathrm{CH}_{2} \mathrm{Cl}_{2} /\right.$ cyclohexane 1:1) to collect all the fractions containing partially and totally iodinated compounds. After evaporation of the solvents, the mixture of iodinated compounds was reengaged under the same conditions as above. After $36 \mathrm{~h}$ at $110{ }^{\circ} \mathrm{C}$, the reaction mixture was filtered through a celite pad (using $\mathrm{CH}_{2} \mathrm{Cl}_{2}$ ) and the solvent was removed under vacuum. The crude mixture was purified by column chromatography $\left(\mathrm{SiO}_{2}, \mathrm{CH}_{2} \mathrm{Cl}_{2} /\right.$ cyclohexane 10:90) to yield the iodinated compound $\mathbf{2 b}$ as a yellow/orange solid $(521.8 \mathrm{mg}, 0.38 \mathrm{mmol}, 83 \%) . R_{\mathrm{f}}=0.45$ $\left(\mathrm{CH}_{2} \mathrm{Cl}_{2} /\right.$ cyclohexane, 50:50); ${ }^{1} \mathrm{H}$ NMR (300 MHz, $\left.\mathrm{CD}_{2} \mathrm{Cl}_{2}, 25^{\circ} \mathrm{C}\right): \delta=7.50$ (AA'BB' pattern, ${ }^{3} \mathrm{~J}=8.7$ $\left.\mathrm{Hz}, 10 \mathrm{H}, \mathrm{H}_{\mathrm{b}}\right), 6.77\left(\mathrm{AA}^{\prime} \mathrm{BB}^{\prime}\right.$ pattern, $\left.{ }^{3} J=8.7 \mathrm{~Hz}, 10 \mathrm{H}, \mathrm{H}_{\mathrm{a}}\right) \mathrm{ppm} .{ }^{13} \mathrm{C}\left\{{ }^{1} \mathrm{H}\right\} \mathrm{NMR}\left(75 \mathrm{MHz}, \mathrm{CD}_{2} \mathrm{Cl}_{2}, 25\right.$ 
$\left.{ }^{\circ} \mathrm{C}\right): \delta=196.1\left(\mathrm{C}^{1}\right), 137.8\left(\mathrm{C}^{5}\right), 134.5\left(\mathrm{C}^{4}\right), 128.9\left(\mathrm{C}^{3}\right), 105.9\left(\mathrm{C}^{2}\right), 95.6\left(\mathrm{C}^{6}\right) \mathrm{ppm}$. MS $\left(\mathrm{DCI} / \mathrm{CH}_{4}\right): \mathrm{m} / \mathrm{z}:$ $1303.05[\mathrm{M}+\mathrm{H}-2 \mathrm{CO}]^{+}$. The data match those reported in the literature. ${ }^{[12]}$

$\eta^{5}$-1,2,3,4,5-Penta-( $p$-iodophenyl)cyclopentadienyl hydrotris $\{6$-[(ethylsulfanyl)methyl]indazol-1yl\}borate ruthenium(II) (4b):

Conditions A (via ligand exchange on complex 2b): In a dry tube designed for microwave irradiation and under argon, compound 3 (160 mg, $0.20 \mathrm{mmol}, 2.0$ equiv.) and iodo $\eta^{5}$-1,2,3,4,5-penta-(4iodophenyl)cyclopentadienyl dicarbonyl ruthenium(II) $2 \mathbf{b}(140 \mathrm{mg}, 0.10 \mathrm{mmol}, 1.0$ equiv.) were introduced followed by degassed anhydrous acetonitrile $(4 \mathrm{~mL})$. The tube was sealed and the reaction mixture was heated under microwave irradiation at $100{ }^{\circ} \mathrm{C}$ for $3 \times 10 \mathrm{~min}$. A pressure of 5 bar was achieved and it was released between heating cycles. The completion of the reaction was monitored by TLC. The resulting mixture was diluted with $\mathrm{CH}_{2} \mathrm{Cl}_{2}$ and filtered through a pad of silica gel. The solvents were removed under reduced pressure and the residue was purified by column chromatography $\left(\mathrm{SiO}_{2}\right.$, $\mathrm{CH}_{2} \mathrm{Cl}_{2} /$ cyclohexane 50:50) to afford compound $\mathbf{4 b}(94.7 \mathrm{mg}, 0.05 \mathrm{mmol}, 52 \%)$ as an orange solid. Conditions B (via Br/I exchange on complex 4a): In a dry Schlenk tube were successively added a magnetic stirrer bar, $\mathrm{NaI}$ ( $99.8 \mathrm{mg}, 0.66 \mathrm{mmol}, 10$ equiv.), complex $4 \mathbf{a}$ (100 mg, $65 \mu \mathrm{mol}, 1.0$ equiv.) and $\mathrm{CuI}(6.2 \mathrm{mg}, 33 \mu \mathrm{mol}, 0.5$ equiv.). It was briefly evacuated and backfilled with argon. Degassed dry 1,4-dioxane $(390 \mu \mathrm{L})$ and $( \pm)$-trans- $N, N$-dimethyl-1,2-cyclohexanediamine $(10 \mu \mathrm{L}, 66 \mu$ mol, 1.0 equiv.) were then added under argon. The reaction mixture was heated at $110{ }^{\circ} \mathrm{C}$ for $36 \mathrm{~h}$ in the dark. The reaction mixture was then filtered through a celite pad (using $\mathrm{CH}_{2} \mathrm{Cl}_{2}$ ) and the solvent was removed under vacuum. The crude mixture was quickly purified by column chromatography $\left(\mathrm{SiO}_{2}\right.$, $\mathrm{CH}_{2} \mathrm{Cl}_{2} /$ cyclohexane 1:1) to collect all the fractions containing iodinated compounds. After evaporation of the solvents, the mixture of iodinated compounds was reengaged under the same conditions as above. After $36 \mathrm{~h}$ at $110^{\circ} \mathrm{C}$, the reaction mixture was filtered on a celite pad (using $\mathrm{CH}_{2} \mathrm{Cl}_{2}$ ) and the solvent was removed under vacuum. The crude mixture was purified by column chromatography $\left(\mathrm{SiO}_{2}\right.$, $\mathrm{CH}_{2} \mathrm{Cl}_{2} /$ cyclohexane gradient from 10:90 up to 50:50) to yield the iodinated compound $\mathbf{4 b}$ as an orange solid (51.3 mg, $29 \mu \mathrm{mol}, 44 \%) . R_{\mathrm{f}}=0.75\left(\mathrm{CH}_{2} \mathrm{Cl}_{2} /\right.$ cyclohexane, 50:50); ${ }^{1} \mathrm{H} \mathrm{NMR}\left(300 \mathrm{MHz}, \mathrm{CD}_{2} \mathrm{Cl}_{2}\right.$, $25{ }^{\circ} \mathrm{C}$ ): $\delta=7.87$ (br. s, $3 \mathrm{H}, \mathrm{H}_{\mathrm{d}}$ ), $7.78\left(\mathrm{~d},{ }^{4} J=0.6 \mathrm{~Hz}, 3 \mathrm{H}, \mathrm{H}_{\mathrm{a}}\right.$ ), 7.39 (AA'BB' pattern, ${ }^{3} J=8.5 \mathrm{~Hz}, 10 \mathrm{H}$, $\left.\mathrm{H}_{\mathrm{i}}\right), 7.35\left(\mathrm{dd},{ }^{3} J=8.4 \mathrm{~Hz},{ }^{4} J=0.6 \mathrm{~Hz}, 3 \mathrm{H}, \mathrm{H}_{\mathrm{c}}\right), 7.08\left(\mathrm{AA}{ }^{\prime} \mathrm{BB}\right.$ ' pattern, $\left.{ }^{3} J=8.5 \mathrm{~Hz}, 10 \mathrm{H}, \mathrm{H}_{\mathrm{h}}\right), 7.04(\mathrm{dd}$, $\left.{ }^{3} J=8.4 \mathrm{~Hz},{ }^{4} J=1.4 \mathrm{~Hz}, 3 \mathrm{H}, \mathrm{H}_{\mathrm{b}}\right), 3.90\left(\mathrm{~s}, 6 \mathrm{H}, \mathrm{H}_{\mathrm{e}}\right), 2.46\left(\mathrm{q},{ }^{3} J=7.4 \mathrm{~Hz}, 6 \mathrm{H}, \mathrm{H}_{\mathrm{f}}\right), 1.27\left(\mathrm{t},{ }^{3} J=7.4 \mathrm{~Hz}, 9 \mathrm{H}\right.$, $\left.\mathrm{H}_{\mathrm{g}}\right)$ ppm. ${ }^{13} \mathrm{C}\left\{{ }^{1} \mathrm{H}\right\}$ NMR $\left(126 \mathrm{MHz}, \mathrm{CD}_{2} \mathrm{Cl}_{2}, 25^{\circ} \mathrm{C}\right): \delta=144.0\left(\mathrm{C}^{2}\right), 140.7\left(\mathrm{C}^{1}\right), 138.2\left(\mathrm{C}^{5}\right), 137.0\left(\mathrm{C}^{13}\right)$, 135.7 $\left(\mathrm{C}^{14}\right), 133.2\left(\mathrm{C}^{12}\right), 122.7\left(\mathrm{C}^{4}\right), 122.4\left(\mathrm{C}^{7}\right), 120.4\left(\mathrm{C}^{3}\right), 111.3\left(\mathrm{C}^{6}\right), 94.1\left(\mathrm{C}^{15}\right), 87.5\left(\mathrm{C}^{11}\right), 36.9\left(\mathrm{C}^{8}\right)$, $25.7\left(\mathrm{C}^{9}\right), 14.7\left(\mathrm{C}^{10}\right)$ ppm. HRMS $\left(\mathrm{ESI}^{+}\right)$: calcd. for $\mathrm{C}_{65} \mathrm{H}_{54} \mathrm{BI}_{5} \mathrm{~N}_{6} \mathrm{RuS}_{3}[\mathrm{M}]^{+}: 1761.7955$, found 1761.7992 .

\section{General procedure for the synthesis of gears 5, 6 and 7 via Suzuki-Miyaura cross-couplings:}

In a dry Schlenk tube under argon, pentaaryl bromide $\mathbf{4 a}(25 \mathrm{mg}, 16 \mu$ mol, 1.0 equiv.), palladium(II) acetate $\left(1.1 \mathrm{mg}, 4.9 \mu \mathrm{mol}, 0.3\right.$ equiv.), $\mathrm{K}_{3} \mathrm{PO}_{4}(35 \mathrm{mg}, 170 \mu \mathrm{mol}, 10.6$ equiv.), the appropriate arylboronic acid ( $330 \mu \mathrm{mol}, 20$ equiv.) and 2-dicyclohexylphosphino-2'-6'-dimethoxybiphenyl (SPhos) ( $4 \mathrm{mg}, 10 \mu \mathrm{mol}, 0.6$ equiv.) were successively introduced and degassed anhydrous toluene $(2 \mathrm{~mL}$ ) was added. The resulting suspension was stirred at $100{ }^{\circ} \mathrm{C}$ for $24 \mathrm{~h}$ and a second amount of palladium(II) acetate $\left(1.1 \mathrm{mg}, 4.9 \mu \mathrm{mol}, 0.3\right.$ equiv.), $\mathrm{K}_{3} \mathrm{PO}_{4}(35 \mathrm{mg}, 170 \mu \mathrm{mol}, 10.6$ equiv.), the appropriate arylboronic acid (330 $\mu$ mol, 20 equiv.) and SPhos $(4 \mathrm{mg}, 10 \mu \mathrm{mol}, 0.6$ equiv.) were introduced. The reaction mixture was further stirred at $100{ }^{\circ} \mathrm{C}$ for $24 \mathrm{~h}$ and the completion of the reaction was monitored by TLC. The reaction mixture was cooled to room temperature, filtered through a celite pad (using $\mathrm{CH}_{2} \mathrm{Cl}_{2}$ ) and the solvents evaporated in vacuo. Purification by column chromatography yielded the corresponding product $\mathbf{5 , 6}$ or $\mathbf{7}$. 


\section{$\eta^{5}$-1,2,3,4,5-Penta-(p-tert-butylbiphenyl)cyclopentadienyl hydrotris $\quad\{6$-[(ethylsulfanyl)methyl $]$}

indazol-1-yl\}borate ruthenium(II) (5):

4-tert-Butylphenylboronic acid ( $2 \times 60 \mathrm{mg})$ was used as coupling partner. The crude product was purified by column chromatography $\left(\mathrm{SiO}_{2}\right.$, cyclohexane/ $\left.\mathrm{CH}_{2} \mathrm{Cl}_{2} 70: 30\right)$ followed by a precipitation in a $\mathrm{CH}_{2} \mathrm{Cl}_{2} / \mathrm{CH}_{3} \mathrm{OH}$ mixture (1:1). Complex 5 (24 mg, $\left.13 \mu \mathrm{mol}, 82 \%\right)$ was obtained as a yellow-orange solid. $R_{\mathrm{f}}=0.50$ (cyclohexane/ $\left.\mathrm{CH}_{2} \mathrm{Cl}_{2}, 50: 50\right) ;{ }^{1} \mathrm{H} \mathrm{NMR}\left(500 \mathrm{MHz}, \mathrm{CD}_{2} \mathrm{Cl}_{2}, 25^{\circ} \mathrm{C}\right): \delta=8.03\left(\mathrm{~d},{ }^{3} J=0.8\right.$ $\mathrm{Hz}, 3 \mathrm{H}, \mathrm{H}_{\mathrm{a}}$ ), 7.92 (br. s, 3H, $\mathrm{H}_{\mathrm{d}}$ ), 7.56 (AA'BB' pattern, ${ }^{3} J=8.7 \mathrm{~Hz}, 10 \mathrm{H}, \mathrm{H}_{\mathrm{h}}$ ), 7.47 (AA'BB' pattern, $\left.{ }^{3} J=8.8 \mathrm{~Hz}, 10 \mathrm{H}, \mathrm{H}_{\mathrm{j}}\right), 7.39$ (AA'BB' pattern, ${ }^{3} J=8.8 \mathrm{~Hz}, 10 \mathrm{H}, \mathrm{H}_{\mathrm{k}}$ ), 7.34 (AA'BB' pattern, ${ }^{3} J=8.7 \mathrm{~Hz}$, $\left.10 \mathrm{H}, \mathrm{H}_{\mathrm{i}}\right), 7.31\left(\mathrm{dd},{ }^{3} \mathrm{~J}=8.3 \mathrm{~Hz},{ }^{4} J=0.8 \mathrm{~Hz}, 3 \mathrm{H}, \mathrm{H}_{\mathrm{b}}\right), 7.00\left(\mathrm{dd},{ }^{3} J=8.4 \mathrm{~Hz},{ }^{4} J=1.4 \mathrm{~Hz}, 3 \mathrm{H}, \mathrm{H}_{\mathrm{c}}\right), 3.91$ (s, 6H, $\left.\mathrm{H}_{\mathrm{e}}\right), 2.48\left(\mathrm{q},{ }^{3} J=7.4 \mathrm{~Hz}, 6 \mathrm{H}, \mathrm{H}_{\mathrm{f}}\right), 1.30\left(\mathrm{~s}, 45 \mathrm{H}, \mathrm{H}_{\mathrm{l}}\right), 1.28\left(\mathrm{t},{ }^{3} \mathrm{~J}=7.4 \mathrm{~Hz}, 9 \mathrm{H}, \mathrm{H}_{\mathrm{g}}\right) \mathrm{ppm} .{ }^{13} \mathrm{C}\left\{{ }^{1} \mathrm{H}\right\}$ NMR (126 MHz, $\left.\mathrm{CD}_{2} \mathrm{Cl}_{2}, 25^{\circ} \mathrm{C}\right): \delta=150.9\left(\mathrm{C}^{19}\right), 144.0\left(\mathrm{C}^{2}\right), 140.9\left(\mathrm{C}^{1}\right), 139.8\left(\mathrm{C}^{15}\right), 137.7\left(\mathrm{C}^{5}\right), 137.6$ $\left(\mathrm{C}^{16}\right), 134.6\left(\mathrm{C}^{13}\right), 133.3\left(\mathrm{C}^{12}\right), 126.7\left(\mathrm{C}^{17}\right), 126.1\left(\mathrm{C}^{18}\right), 125.9\left(\mathrm{C}^{14}\right), 122.6\left(\mathrm{C}^{7}\right), 122.4\left(\mathrm{C}^{4}\right), 120.4\left(\mathrm{C}^{3}\right)$, $111.4\left(\mathrm{C}^{6}\right), 88.3\left(\mathrm{C}^{11}\right), 36.9\left(\mathrm{C}^{8}\right), 34.8\left(\mathrm{C}^{20}\right), 31.4\left(\mathrm{C}^{21}\right), 25.7\left(\mathrm{C}^{9}\right), 14.8\left(\mathrm{C}^{10}\right)$ ppm. HRMS (MALDI): calcd. for $\mathrm{C}_{115} \mathrm{H}_{120} \mathrm{BN}_{6} \mathrm{RuS}_{3}[\mathrm{MH}]^{+}: 1793.7913$, found 1793.7889. Crystal data: Crystals suitable for XRay diffraction were obtained from the slow diffusion of methanol in a toluene solution of complex $\mathbf{5}$. CCDC-1943538 contains the supplementary crystallographic data for this paper. These data can be obtained free of charge from The Cambridge Crystallographic Data Centre via www.ccdc.cam.ac.uk/data_request/cif. Selected data for 5: $\mathrm{C}_{115} \mathrm{H}_{119} \mathrm{BN}_{6} \mathrm{RuS}_{3}, 2 \mathrm{C}_{7} \mathrm{H}_{8} M=1977.48$, triclinic, space group $P \overline{1}, a=17.6038(8) \AA, b=8.0649(7) \AA, c=19.7291(9) \AA, \alpha=109.049(2)^{\circ}, \beta=92.140(3)^{\circ}, \beta=96.350(2)^{\circ}$ $V=5876.1(4) \AA^{3}, Z=2$, crystal size $0.24 \times 0.22 \times 0.18 \mathrm{~mm}^{3}, 150409$ reflections collected (23944 independent, Rint $=0.0874), 1742$ parameters, 2402 restraints, $R 1[\mathrm{I}>2 \sigma(\mathrm{I})]=0.0694, \quad w R 2$ [all data $]=0.2199$, largest diff. peak and hole: 1.271 and $-0.825 \mathrm{e}^{-3}$.

\section{$\eta^{5}$-1,2,3,4,5-Penta-(3,5-dimethylbiphenyl)cyclopentadienyl hydrotris \{6-[(ethylsulfanyl)methyl] indazol-1-yl\}borate ruthenium(II) (6):}

3,5-Dimethylphenylboronic acid ( $2 \times 49 \mathrm{mg}$ ) was used as coupling partner. The crude product was purified by column chromatography $\left(\mathrm{SiO}_{2}\right.$, cyclohexane/ $\left.\mathrm{CH}_{2} \mathrm{Cl}_{2} 0-50 \%\right)$ to yield complex 6 (14 mg, 9 $\mu \mathrm{mol}, 52 \%)$ as a yellow-orange solid. $R_{\mathrm{f}}=0.50$ (cyclohexane $\left./ \mathrm{CH}_{2} \mathrm{Cl}_{2}, 50: 50\right) ;{ }^{1} \mathrm{H}$ NMR $(500 \mathrm{MHz}$, $\mathrm{CD}_{2} \mathrm{Cl}_{2}, 25^{\circ} \mathrm{C}$ ): $\delta=8.03$ (br. s, $3 \mathrm{H}, \mathrm{H}_{\mathrm{a}}$ ), 7.92 (br. s, $3 \mathrm{H}, \mathrm{H}_{\mathrm{d}}$ ), 7.56 (AA'BB' pattern, ${ }^{3} \mathrm{~J}=8.5 \mathrm{~Hz}, 10 \mathrm{H}$, $\left.\mathrm{H}_{\mathrm{h}}\right), 7.33\left(\mathrm{AA}\right.$ 'BB' pattern, $\left.{ }^{3} J=8.5 \mathrm{~Hz}, 10 \mathrm{H}, \mathrm{H}_{\mathrm{i}}\right), 7.32\left(\mathrm{~d},{ }^{3} J=8.4 \mathrm{~Hz}, 3 \mathrm{H}, \mathrm{H}_{\mathrm{b}}\right), 7.16\left(\mathrm{~s}, 10 \mathrm{H}, \mathrm{H}_{\mathrm{j}}\right), 7.01$ $\left(\mathrm{dd},{ }^{3} J=8.4 \mathrm{~Hz},{ }^{4} J=1.3 \mathrm{~Hz}, 3 \mathrm{H}, \mathrm{H}_{\mathrm{c}}\right), 6.94\left(\mathrm{~s}, 5 \mathrm{H}, \mathrm{H}_{\mathrm{k}}\right), 3.91\left(\mathrm{~s}, 6 \mathrm{H}, \mathrm{H}_{\mathrm{e}}\right), 2.48\left(\mathrm{q},{ }^{3} J=7.4 \mathrm{~Hz}, 6 \mathrm{H}, \mathrm{H}_{\mathrm{f}}\right)$, $2.30\left(\mathrm{~s}, 30 \mathrm{H}, \mathrm{H}_{\mathrm{l}}\right), 1.28\left(\mathrm{t},{ }^{3} \mathrm{~J}=7.4 \mathrm{~Hz}, 9 \mathrm{H}, \mathrm{H}_{\mathrm{g}}\right) \mathrm{ppm} .{ }^{13} \mathrm{C}\left\{{ }^{1} \mathrm{H}\right\} \mathrm{NMR}\left(126 \mathrm{MHz}, \mathrm{CD}_{2} \mathrm{Cl}_{2}, 25^{\circ} \mathrm{C}\right): \delta=144.1$ $\left(\mathrm{C}^{2}\right), 141.0\left(\mathrm{C}^{1}\right), 140.4\left(\mathrm{C}^{16}\right), 140.3\left(\mathrm{C}^{15}\right), 138.7\left(\mathrm{C}^{18}\right), 137.7\left(\mathrm{C}^{5}\right), 134.6\left(\mathrm{C}^{13}\right), 133.3\left(\mathrm{C}^{12}\right), 129.3\left(\mathrm{C}^{19}\right)$, $126.0\left(\mathrm{C}^{14}\right), 125.0\left(\mathrm{C}^{17}\right), 122.6\left(\mathrm{C}^{7}\right), 122.4\left(\mathrm{C}^{4}\right), 120.4\left(\mathrm{C}^{3}\right), 111.4\left(\mathrm{C}^{6}\right), 88.3\left(\mathrm{C}^{11}\right), 36.9\left(\mathrm{C}^{8}\right), 25.7\left(\mathrm{C}^{9}\right)$, $21.5\left(\mathrm{C}^{20}\right), 14.8\left(\mathrm{C}^{10}\right)$ ppm. HRMS (MALDI): calcd. for $\mathrm{C}_{105} \mathrm{H}_{99} \mathrm{BN}_{6} \mathrm{RuS}_{3}[\mathrm{M}]^{+}: 1653.6278$, found 1653.6239 .

\section{$\eta^{5}$-1,2,3,4,5-Penta-(3,5-di-tert-butylbiphenyl)cyclopentadienyl hydro $\quad \operatorname{tris}\{6-[($ ethylsulfanyl) methyl]indazol-1-yl\}borate ruthenium(II) (7):}

3,5-Di-tert-butylphenylboronic acid $(2 \times 77 \mathrm{mg})$ was used as coupling partner. The crude product was purified by column chromatography $\left(\mathrm{SiO}_{2}\right.$, cyclohexane/ $\left.\mathrm{CH}_{2} \mathrm{Cl}_{2} 70: 30\right)$ to yield complex 7 (22 $\mathrm{mg}, 11$ $\mu \mathrm{mol}, 65 \%$ ) as a yellow-orange solid. $R_{\mathrm{f}}=0.55$ (cyclohexane $\left./ \mathrm{CH}_{2} \mathrm{Cl}_{2}, 50: 50\right) ;{ }^{1} \mathrm{H} \mathrm{NMR}(500 \mathrm{MHz}$, $\mathrm{CD}_{2} \mathrm{Cl}_{2}, 25^{\circ} \mathrm{C}$ ): $\delta=8.06$ (br. s, $3 \mathrm{H}, \mathrm{H}_{\mathrm{a}}$ ) 7.93 (br. s, $3 \mathrm{H}, \mathrm{H}_{\mathrm{d}}$ ), 7.62 (AA'BB' pattern, ${ }^{3} J=8.5 \mathrm{~Hz}, 10 \mathrm{H}$, $\left.\mathrm{H}_{\mathrm{h}}\right), 7.39\left(\mathrm{~m}, 25 \mathrm{H}, \mathrm{H}_{\mathrm{i}}, \mathrm{H}_{\mathrm{j}}\right.$ and $\left.\mathrm{H}_{\mathrm{k}}\right), 7.35\left(\mathrm{~d},{ }^{3} \mathrm{~J}=8.4 \mathrm{~Hz}, 3 \mathrm{H}, \mathrm{H}_{\mathrm{b}}\right), 7.01\left(\mathrm{dd},{ }^{3} J=8.4 \mathrm{~Hz},{ }^{4} J=1.4 \mathrm{~Hz}, 3 \mathrm{H}\right.$, $\left.\mathrm{H}_{\mathrm{c}}\right), 3.91\left(\mathrm{~s}, 6 \mathrm{H}, \mathrm{H}_{\mathrm{e}}\right), 2.48\left(\mathrm{q},{ }^{3} J=7.4 \mathrm{~Hz}, 6 \mathrm{H}, \mathrm{H}_{\mathrm{f}}\right), 1.32\left(\mathrm{~s}, 90 \mathrm{H}, \mathrm{H}_{\mathrm{l}}\right), 1.29\left(\mathrm{t},{ }^{3} J=7.4 \mathrm{~Hz}, 9 \mathrm{H}, \mathrm{H}_{\mathrm{g}}\right) \mathrm{ppm}$. ${ }^{13} \mathrm{C}\left\{{ }^{1} \mathrm{H}\right\} \mathrm{NMR}\left(126 \mathrm{MHz}, \mathrm{CD}_{2} \mathrm{Cl}_{2}, 25{ }^{\circ} \mathrm{C}\right): \delta=151.7\left(\mathrm{C}^{18}\right), 144.1\left(\mathrm{C}^{2}\right), 141.3\left(\mathrm{C}^{15}\right), 140.9\left(\mathrm{C}^{1}\right), 140.0$ $\left(C^{16}\right), 137.7\left(C^{5}\right), 134.7\left(C^{13}\right), 132.3\left(C^{12}\right), 126.4\left(C^{14}\right), 122.6\left(C^{7}\right), 122.4\left(C^{4}\right), 121.9\left(C^{19}\right), 121.7\left(C^{17}\right)$, 
$120.5\left(\mathrm{C}^{3}\right), 111.4\left(\mathrm{C}^{6}\right), 88.4\left(\mathrm{C}^{11}\right), 37.0\left(\mathrm{C}^{8}\right), 35.3\left(\mathrm{C}^{20}\right), 31.7\left(\mathrm{C}^{21}\right), 25.7\left(\mathrm{C}^{9}\right), 14.8\left(\mathrm{C}^{10}\right)$ ppm. HRMS (MALDI): calcd. for $\mathrm{C}_{135} \mathrm{H}_{160} \mathrm{BN}_{6} \mathrm{RuS}_{3}[\mathrm{MH}]^{+}: 2074.1047$, found 2074.1011.

$\eta^{5}$-1,2,3,4,5-Penta-\{p-(3,6-di-tert-butylcarbazol-9-yl)phenyl $\} \quad$ cyclopentadienyl hydrotris $\{6-$ [(ethylsulfanyl)methyl]indazol-1-yl\} borate ruthenium(II) (8):

Conditions A (starting from pentaaryl bromide 4a): In a dry Schlenk tube under argon, pentaarylbromide 4a (25 mg, $16 \mu \mathrm{mol}, 1.0$ equiv.), 3,6-di-tert-butyl- $9 H$-carbazole (46 mg, $160 \mu \mathrm{mol}, 10$ equiv.), $\mathrm{CuI}\left(3 \mathrm{mg}, 16 \mu \mathrm{mol}, 1.0\right.$ equiv.), $\mathrm{K}_{3} \mathrm{PO}_{4}(36.5 \mathrm{mg}, 160 \mu \mathrm{mol}, 10$ equiv.) and ( \pm )-trans-1,2cyclohexanediamine ( $4 \mu \mathrm{L}, 33 \mu \mathrm{mol}, 2.0$ equiv.) were successively introduced and degassed anhydrous 1,4-dioxane $(2 \mathrm{~mL})$ was added. The resulting suspension was stirred at $110{ }^{\circ} \mathrm{C}$ for $48 \mathrm{~h}$ in the dark and the completion of the reaction was monitored by TLC. The reaction mixture was cooled to room temperature, filtered through a celite pad (using $\mathrm{CH}_{2} \mathrm{Cl}_{2}$ ) and the solvents evaporated in vacuo. The residue was purified by column chromatography $\left(\mathrm{SiO}_{2}, \mathrm{CH}_{2} \mathrm{Cl}_{2} /\right.$ cyclohexane 20:80) to afford compound $\mathbf{8}$ as an orange-red solid ( $8 \mathrm{mg}, 3.2 \mu \mathrm{mol}, 19 \%$ ).

Conditions $B$ (starting from pentaaryl iodide 4b): In a dry Schlenk tube under argon, penta-aryliodide 4b (29 mg, $16 \mu \mathrm{mol}, 1.0$ equiv.), 3,6-di-tert-butyl-9H-carbazole (46 mg, $160 \mu \mathrm{mol}, 10$ equiv.), CuI (3 $\mathrm{mg}, 16 \mu \mathrm{mol}, 1.0$ equiv.), $\mathrm{K}_{3} \mathrm{PO}_{4}(36.5 \mathrm{mg}, 160 \mu \mathrm{mol}, 10$ equiv.) and ( \pm )-trans-1,2-cyclohexanediamine ( $4 \mu \mathrm{L}, 33 \mu \mathrm{mol}, 2$ equiv.) were successively introduced and degassed anhydrous 1,4-dioxane $(2 \mathrm{~mL})$ was added. The resulting suspension was stirred at $110{ }^{\circ} \mathrm{C}$ for $48 \mathrm{~h}$ in the dark and the completion of the reaction was monitored by TLC. The reaction mixture was cooled to room temperature, filtered through a celite pad (using $\mathrm{CH}_{2} \mathrm{Cl}_{2}$ ) and the solvents evaporated in vacuo. The residue was purified by column chromatography $\left(\mathrm{SiO}_{2}, \mathrm{CH}_{2} \mathrm{Cl}_{2} /\right.$ cyclohexane $\left.20: 80\right)$ to afford compound $\mathbf{8}$ as an orange-red solid (11.7 $\mathrm{mg}, 4.6 \mu \mathrm{mol}, 28 \%) . R_{\mathrm{f}}=0.55$ (cyclohexane $\left./ \mathrm{CH}_{2} \mathrm{Cl}_{2}, 70: 30\right) ;{ }^{1} \mathrm{H} \mathrm{NMR}\left(500 \mathrm{MHz}, \mathrm{CD}_{2} \mathrm{Cl}_{2}, 25^{\circ} \mathrm{C}\right): \delta=$ 8.28 (br. s, 3H, $\mathrm{H}_{\mathrm{a}}$ ), $8.12\left(\mathrm{dd},{ }^{4} J=1.6 \mathrm{~Hz},{ }^{5} J=0.9 \mathrm{~Hz}, 10 \mathrm{H}, \mathrm{H}_{\mathrm{l}}\right), 7.96$ (br. s, 3H, $\mathrm{H}_{\mathrm{d}}$ ), 7.84 (AA'BB' pattern, $\left.{ }^{3} J=8.6 \mathrm{~Hz}, 10 \mathrm{H}, \mathrm{H}_{\mathrm{h}}\right), 7.48\left(\mathrm{~d},{ }^{3} J=8.5 \mathrm{~Hz}, 3 \mathrm{H}, \mathrm{H}_{\mathrm{b}}\right), 7.44\left(\mathrm{AA}^{\prime}{ }^{\prime} \mathrm{BB}\right.$ ' pattern, ${ }^{3} J=8.6 \mathrm{~Hz}, 10 \mathrm{H}$, $\left.\mathrm{H}_{\mathrm{i}}\right), 7.37\left(\mathrm{~m}, 20 \mathrm{H}, \mathrm{H}_{\mathrm{j}}\right.$ and $\left.\mathrm{H}_{\mathrm{k}}\right), 7.09\left(\mathrm{dd},{ }^{3} J=8.5 \mathrm{~Hz},{ }^{4} J=1.4 \mathrm{~Hz}, 3 \mathrm{H}, \mathrm{H}_{\mathrm{c}}\right), 3.92\left(\mathrm{~s}, 6 \mathrm{H}, \mathrm{H}_{\mathrm{e}}\right), 2.47\left(\mathrm{q},{ }^{3} J=\right.$ $\left.7.4 \mathrm{~Hz}, 6 \mathrm{H}, \mathrm{H}_{\mathrm{f}}\right), 1.41\left(\mathrm{~s}, 90 \mathrm{H}, \mathrm{H}_{\mathrm{m}}\right), 1.27\left(\mathrm{t},{ }^{3} \mathrm{~J}=7.4 \mathrm{~Hz}, 9 \mathrm{H}, \mathrm{H}_{\mathrm{g}}\right) \mathrm{ppm} .{ }^{13} \mathrm{C}\left\{{ }^{1} \mathrm{H}\right\} \mathrm{NMR}\left(126 \mathrm{MHz}, \mathrm{CD}_{2} \mathrm{Cl}_{2}\right.$, $\left.25{ }^{\circ} \mathrm{C}\right): \delta=144.2\left(\mathrm{C}^{2}\right), 143.5\left(\mathrm{C}^{19}\right), 140.5\left(\mathrm{C}^{1}\right), 139.3\left(\mathrm{C}^{16}\right), 138.1\left(\mathrm{C}^{5}\right), 137.8\left(\mathrm{C}^{15}\right), 135.3\left(\mathrm{C}^{13}\right), 133.2$ $\left(\mathrm{C}^{12}\right), 125.8\left(\mathrm{C}^{14}\right), 124.1\left(\mathrm{C}^{18}\right), 123.8\left(\mathrm{C}^{21}\right), 122.7\left(\mathrm{C}^{7}\right), 122.7\left(\mathrm{C}^{4}\right), 120.5\left(\mathrm{C}^{3}\right), 116.7\left(\mathrm{C}^{20}\right), 111.5\left(\mathrm{C}^{6}\right)$, 109.6 $\left(\mathrm{C}^{17}\right), 87.8\left(\mathrm{C}^{11}\right), 36.9\left(\mathrm{C}^{8}\right), 35.0\left(\mathrm{C}^{22}\right), 32.1\left(\mathrm{C}^{23}\right), 25.7\left(\mathrm{C}^{9}\right), 14.8\left(\mathrm{C}^{10}\right)$ ppm. HRMS (MALDI): calcd. for $\mathrm{C}_{165} \mathrm{H}_{174} \mathrm{BN}_{11} \mathrm{RuS}_{3}[\mathrm{M}]^{+}: 2519.2314$, found 2519.2317 .

\section{2,6-Diethyl-4,4-difluoro-1,3,5,7-tetramethyl-8-[4-(4,4,5,5-tetramethyl-1,3,2-dioxaborolan-2- yl)phenyl]-4-bora-3a,4a-diaza-s-indacene (9):}

To a solution of 4-(4,4,5,5-tetramethyl-1,3,2-dioxaborolan-2-yl)benzaldehyde (1 g, $4.31 \mathrm{mmol}, 1.0$ equiv.) and 3-ethyl-2,4-dimethyl- $1 \mathrm{H}$-pyrrole (1.2 mL, $8.89 \mathrm{mmol}, 2.0$ equiv.) in $\mathrm{CH}_{2} \mathrm{Cl}_{2}(360 \mathrm{~mL})$ under argon, trifluoroacetic acid ( $30 \mu \mathrm{L}, 0.404 \mathrm{mmol}, 0.1$ equiv.) was added. After $3 \mathrm{~h}$ at room temperature in the dark, DDQ (0.98 g, $4.31 \mathrm{mmol}, 1.0$ equiv.) was added. The solution immediately turned dark purple and was stirred for an additional $30 \mathrm{~min}$ at room temperature. Triethylamine $(13 \mathrm{~mL}, 93.5 \mathrm{mmol}, 21$ equiv.) was introduced and $\mathrm{BF}_{3} \cdot \mathrm{OEt}_{2}$ was then added dropwise until green reflects appeared in the solution (added volume: $9 \mathrm{~mL}$, i.e. $71.7 \mathrm{mmol}, 16.6$ equiv.). The resulting mixture was washed with water $(3 \times 500 \mathrm{~mL})$, dried over $\mathrm{Na}_{2} \mathrm{SO}_{4}$, filtered and evaporated. The crude product was purified by column chromatography $\left(\mathrm{SiO}_{2}, \mathrm{CH}_{2} \mathrm{Cl}_{2} /\right.$ cyclohexane 1:1) to afford compound $\mathbf{9}$ (1.13 g, $2.23 \mathrm{mmol}, 52$ $\%$ ) as a dark red solid. ${ }^{1} \mathrm{H}$ NMR ( $\left.300 \mathrm{MHz}, \mathrm{CD}_{2} \mathrm{Cl}_{2}, 2{ }^{\circ} \mathrm{C}\right): \delta=7.88$ (AA'BB' pattern, ${ }^{3} J=8.2 \mathrm{~Hz}, 2 \mathrm{H}$ ), $7.31\left(\mathrm{AA}{ }^{\prime} \mathrm{BB}\right.$ ' pattern, $\left.{ }^{3} J=8.2 \mathrm{~Hz}, 2 \mathrm{H}\right), 2.49(\mathrm{~s}, 6 \mathrm{H}), 2.32\left(\mathrm{q},{ }^{3} J=7.5 \mathrm{~Hz}, 4 \mathrm{H}\right), 1.38(\mathrm{~s}, 12 \mathrm{H}), 1.27$ (s, $6 \mathrm{H}), 0.99\left(\mathrm{t},{ }^{3} \mathrm{~J}=7.5 \mathrm{~Hz}, 6 \mathrm{H}\right) \mathrm{ppm} .{ }^{13} \mathrm{C}\left\{{ }^{1} \mathrm{H}\right\} \mathrm{NMR}\left(126 \mathrm{MHz}, \mathrm{CD}_{2} \mathrm{Cl}_{2}, 25^{\circ} \mathrm{C}\right): \delta=154.0,140.7,139.0$, 138.9, 135.6, 133.3, 130.9, 128.1, 84.5, 25.2, 17.4, 14.8, $12.7\left(\mathrm{t}, J\left({ }^{13} \mathrm{C}-{ }^{19} \mathrm{~F}\right)=2.3 \mathrm{~Hz}\right), 12.0 \mathrm{ppm} .{ }^{19} \mathrm{~F}$ $\operatorname{NMR}\left(282 \mathrm{MHz}, \mathrm{CD}_{2} \mathrm{Cl}_{2}, 25{ }^{\circ} \mathrm{C}\right): \delta=-145.7\left(\mathrm{q}, J\left({ }^{11} \mathrm{~B}-{ }^{19} \mathrm{~F}\right)=33.3 \mathrm{~Hz}\right) \mathrm{ppm} .{ }^{11} \mathrm{~B} \mathrm{NMR}\left(96 \mathrm{MHz}, \mathrm{CD}_{2} \mathrm{Cl}_{2}\right.$, 
$\left.25{ }^{\circ} \mathrm{C}\right): \delta=30.7,0.8\left(\mathrm{t}, J\left({ }^{11} \mathrm{~B}-{ }^{19} \mathrm{~F}\right)=33.3 \mathrm{~Hz}\right) \mathrm{ppm}$. UV/Vis $\left(\mathrm{C}_{6} \mathrm{H}_{12}\right): \lambda_{\max }(\varepsilon)=525 \mathrm{~nm}(59900$ $\mathrm{mol}^{-1} \mathrm{dm}^{3} \mathrm{~cm}^{-1}$ ). HRMS (ESI ${ }^{+}$): calcd. for $\mathrm{C}_{29} \mathrm{H}_{39} \mathrm{~B}_{2} \mathrm{~F}_{2} \mathrm{~N}_{2} \mathrm{O}_{2}[\mathrm{MH}]^{+}: 507.3166$, found 507.3168. The data match those reported $\left({ }^{1} \mathrm{H}\right.$ NMR and MS) in the literature. ${ }^{[17]}$

\section{$\eta^{5}$-1,2,3,4,5-Penta- $\{p$-[2,6-diethyl-4,4-difluoro-1,3,5,7-tetramethyl-4-bora-3a,4a-diaza-s-indacen- 8-yl]-4,4'-biphenyl $\}$ cyclopentadienyl hydrotris $\{6-[($ ethylsulfanyl)methyl]indazol-1-yl $\}$ borate ruthenium(II) (10):}

In a dry Schlenk tube under argon, pentaaryl bromide $\mathbf{4 a}$ (50 mg, $33 \mu$ mol, 1.0 equiv.), palladium(II) acetate ( $2.5 \mathrm{mg}, 11 \mu \mathrm{mol}, 0.3$ equiv.), $\mathrm{K}_{3} \mathrm{PO}_{4}(70 \mathrm{mg}, 330 \mu \mathrm{mol}, 10$ equiv.), the arylboronic acid pinacol ester 9 (166 mg, $328 \mu \mathrm{mol}, 10$ equiv.) and 2-dicyclohexylphosphino-2'-6'-dimethoxybiphenyl (SPhos) ( $8 \mathrm{mg}, 19.5 \mu \mathrm{mol}, 0.6$ equiv.) were successively introduced in a degassed mixture of toluene/ethanol/water 2:2:1 $(10 \mathrm{~mL})$. The resulting suspension was stirred at $100{ }^{\circ} \mathrm{C}$ for $48 \mathrm{~h}$ and the completion of the reaction was monitored by TLC. The reaction mixture was cooled to room temperature, filtered through a celite pad (using ethyl acetate) and the solvents evaporated in vacuo. The crude product was purified by column chromatography $\left(\mathrm{SiO}_{2}, \mathrm{CH}_{2} \mathrm{Cl}_{2} / \mathrm{MeOH} 0-5 \%\right)$ followed by precipitation in a $\mathrm{CH}_{2} \mathrm{Cl}_{2} / \mathrm{MeOH}$ mixture (1:1) to afford complex 10 (35.7 mg, $\left.11.8 \mu \mathrm{mol}, 36 \%\right)$ as a red solid. $R_{\mathrm{f}}=0.60\left(\mathrm{CH}_{2} \mathrm{Cl}_{2} / \mathrm{CH}_{3} \mathrm{OH}, 95: 5\right) ;{ }^{1} \mathrm{H} \mathrm{NMR}\left(500 \mathrm{MHz}, \mathrm{CD}_{2} \mathrm{Cl}_{2}, 25^{\circ} \mathrm{C}\right): \delta=8.09\left(\mathrm{~s}, 3 \mathrm{H}, \mathrm{H}_{\mathrm{a}}\right), 7.97$ (br. s, $\left.3 \mathrm{H}, \mathrm{H}_{\mathrm{d}}\right), 7.76-7.67\left(\mathrm{~m}, 20 \mathrm{H}, \mathrm{H}_{\mathrm{h}}\right.$ and $\left.\mathrm{H}_{\mathrm{j}}\right), 7.52\left(\mathrm{AA}^{\prime} \mathrm{BB}\right.$ ' pattern, $\left.{ }^{3} J=8.6 \mathrm{~Hz}, 10 \mathrm{H}, \mathrm{H}_{\mathrm{i}}\right), 7.39\left(\mathrm{~d},{ }^{3} J\right.$ $\left.=8.4 \mathrm{~Hz}, 3 \mathrm{H}, \mathrm{H}_{\mathrm{b}}\right), 7.32\left(\mathrm{AA}^{\prime} \mathrm{BB}^{\prime}\right.$ pattern, $\left.{ }^{3} J=8.7 \mathrm{~Hz}, 10 \mathrm{H}, \mathrm{H}_{\mathrm{k}}\right), 7.06\left(\mathrm{dd},{ }^{3} J=8.4 \mathrm{~Hz},{ }^{4} J=1.4 \mathrm{~Hz}, 3 \mathrm{H}\right.$, $\left.\mathrm{H}_{\mathrm{c}}\right), 3.94\left(\mathrm{~s}, 6 \mathrm{H}, \mathrm{H}_{\mathrm{e}}\right), 2.50\left(\mathrm{q},{ }^{3} J=7.4 \mathrm{~Hz}, 6 \mathrm{H}, \mathrm{H}_{\mathrm{f}}\right), 2.47\left(\mathrm{~s}, 30 \mathrm{H}, \mathrm{H}_{\mathrm{o}}\right), 2.29$ (q, ${ }^{3} J=7.5 \mathrm{~Hz}, 20 \mathrm{H}, \mathrm{H}_{\mathrm{m}}$ ), $1.31\left(\mathrm{~s}, 30 \mathrm{H}, \mathrm{H}_{\mathrm{l}}\right), 1.30\left(\mathrm{t},{ }^{3} J=7.4 \mathrm{~Hz}, 9 \mathrm{H}, \mathrm{H}_{\mathrm{g}}\right), 0.96\left(\mathrm{t},{ }^{3} \mathrm{~J}=7.5 \mathrm{~Hz}, 30 \mathrm{H}, \mathrm{H}_{\mathrm{n}}\right) \mathrm{ppm} .{ }^{13} \mathrm{C}\left\{{ }^{1} \mathrm{H}\right\} \mathrm{NMR}(126$ $\left.\mathrm{MHz}, \mathrm{CD}_{2} \mathrm{Cl}_{2}, 25{ }^{\circ} \mathrm{C}\right): \delta=154.1\left(\mathrm{C}^{24}\right), 144.2\left(\mathrm{C}^{2}\right), 141.1,\left(\mathrm{C}^{1}\right), 140.8\left(\mathrm{C}^{16}\right), 140.4\left(\mathrm{C}^{20}\right), 139.2\left(\mathrm{C}^{15}\right)$, $138.9\left(\mathrm{C}^{22}\right), 138.0\left(\mathrm{C}^{5}\right), 135.3\left(\mathrm{C}^{19}\right), 134.9\left(\mathrm{C}^{13}\right), 133.9\left(\mathrm{C}^{12}\right), 133.3\left(\mathrm{C}^{23}\right), 131.0\left(\mathrm{C}^{21}\right), 129.3\left(\mathrm{C}^{18}\right), 127.6$ $\left(\mathrm{C}^{17}\right), 126.1\left(\mathrm{C}^{14}\right), 122.6\left(\mathrm{C}^{4}\right.$ and $\left.\mathrm{C}^{7}\right), 120.4\left(\mathrm{C}^{3}\right), 111.5\left(\mathrm{C}^{6}\right), 88.5\left(\mathrm{C}^{11}\right), 37.0\left(\mathrm{C}^{8}\right), 25.8\left(\mathrm{C}^{9}\right), 17.4\left(\mathrm{C}^{26}\right)$, $14.8\left(\mathrm{C}^{10}\right.$ and $\left.\mathrm{C}^{27}\right), 12.7\left(\mathrm{t}, J\left({ }^{13} \mathrm{C}-{ }^{19} \mathrm{~F}\right)=2.3 \mathrm{~Hz}, \mathrm{C}^{28}\right), 12.1\left(\mathrm{C}^{25}\right) \mathrm{ppm} .{ }^{19} \mathrm{~F}$ NMR $\left(282 \mathrm{MHz}, \mathrm{CD}_{2} \mathrm{Cl}_{2}, 25\right.$ $\left.{ }^{\circ} \mathrm{C}\right): \delta=-145.7\left(\mathrm{q}, J\left({ }^{11} \mathrm{~B}-{ }^{19} \mathrm{~F}\right)=33.3 \mathrm{~Hz}\right) \mathrm{ppm} .{ }^{11} \mathrm{~B} \mathrm{NMR}\left(96 \mathrm{MHz}, \mathrm{CD}_{2} \mathrm{Cl}_{2}, 25{ }^{\circ} \mathrm{C}\right): \delta=0.7\left(\mathrm{t}, J\left({ }^{11} \mathrm{~B}-\right.\right.$ $\left.\left.{ }^{19} \mathrm{~F}\right)=33.3 \mathrm{~Hz}\right) \mathrm{ppm}$. UV/Vis $\left(\mathrm{C}_{6} \mathrm{H}_{12}\right): \lambda_{\max }(\varepsilon)=280(9900), 528 \mathrm{~nm}\left(15000 \mathrm{~mol}^{-1} \mathrm{dm}^{3} \mathrm{~cm}^{-1}\right)$. HRMS (MALDI): calcd. for $\mathrm{C}_{180} \mathrm{H}_{184} \mathrm{~B}_{6} \mathrm{~F}_{10} \mathrm{~N}_{16} \mathrm{RuS}_{3}[\mathrm{M}]^{+}: 3024.3599$, found 3024.3523.

\section{Nickel(II) 5,10,15-tris(3,5-di-tert-butylphenyl)-20-[4-(4,4,5,5-tetramethyl-1,3,2-dioxaborolan-2- yl)phenyl)]porphyrin (11):}

To a solution of freshly distilled pyrrole $(1.0 \mathrm{~mL}, 14.31 \mathrm{mmol}, 4.0$ equiv. $)$ in anhydrous $\mathrm{CHCl}_{3}(1.5 \mathrm{~L})$, 3,5-di-tert-butylbenzaldehyde (2.34 g, $10.73 \mathrm{mmol}, 3.0$ equiv.), 4-(tetramethyl-1,3,2-dioxaborolan-2yl)benzaldehyde $\left(0.83 \mathrm{~g}, 3.58 \mathrm{mmol}, 1.0\right.$ equiv.) and $\mathrm{BF}_{3} \cdot \mathrm{OEt}_{2}(0.54 \mathrm{~mL}, 4.30 \mathrm{mmol}, 1.2$ equiv.) were added under argon. After stirring the reaction mixture for $1 \mathrm{~h}$ at room temperature, chloranil $(3.82 \mathrm{~g}$, $15.55 \mathrm{mmol}, 4.35$ equiv.) was added and the mixture was refluxed for $30 \mathrm{~min}$. After cooling to room temperature, the crude product was washed with water and evaporated to dryness. Then, the residue was purified by column chromatography $\left(\mathrm{SiO}_{2}\right.$, cyclohexane/ $\mathrm{CH}_{2} \mathrm{Cl}_{2}$ gradient from $4: 1$ to $1: 1$ ) to yield 5,10,15-tris(3,5-di-tert-butylphenyl)-20-[4-(4,4,5,5-tetramethyl-1,3,2-dioxaborolan-2-yl)phenyl)] porphyrin (500 $\mathrm{mg}, 0.46 \mathrm{mmol}, 13 \%)$ as a purple solid. In a dry Schlenk tube under argon, a solution of this free-base porphyrin (226 mg, $0.21 \mathrm{mmol}, 1.0$ equiv.) and nickel(II) acetylacetonate $\mathrm{Ni}(\mathrm{acac})_{2}(216$ $\mathrm{mg}, 0.84 \mathrm{mmol}, 4.0$ equiv.) in dry toluene $(20 \mathrm{~mL})$ was heated at $110{ }^{\circ} \mathrm{C}$ overnight. The mixture was cooled to room temperature and volatiles were evaporated. The crude product was purified by column chromatography $\left(\mathrm{SiO}_{2}\right.$, cyclohexane/ $\left.\mathrm{CH}_{2} \mathrm{Cl}_{2} 2: 1\right)$ to yield nickel porphyrin 11 (152 $\mathrm{mg}, 0.13 \mathrm{mmol}$, $64 \%)$ as a red solid. $R_{\mathrm{f}}=0.60$ (cyclohexane/ $\left.\mathrm{CH}_{2} \mathrm{Cl}_{2}, 2: 1\right) ;{ }^{1} \mathrm{H} \mathrm{NMR}\left(500 \mathrm{MHz}, \mathrm{CDCl}_{3}, 25^{\circ} \mathrm{C}\right): \delta=8.80$ $\left(\mathrm{m}, 4 \mathrm{H}, \mathrm{H}_{\beta}\right), 8.77\left(\mathrm{~d},{ }^{3} J=5.0 \mathrm{~Hz}, 2 \mathrm{H}, \mathrm{H}_{\beta}\right), 8.72\left(\mathrm{~d},{ }^{3} \mathrm{~J}=5.0 \mathrm{~Hz}, 2 \mathrm{H}, \mathrm{H}_{\beta}\right), 8.11$ (AA'BB' pattern, ${ }^{3} J=8.0$ $\mathrm{Hz}, 2 \mathrm{H}, \mathrm{H}_{11}$ ), 8.04 (AA'BB' pattern, $\left.{ }^{3} J=8.0 \mathrm{~Hz}, 2 \mathrm{H}, \mathrm{H}_{12}\right), 7.88-7.85\left(\mathrm{~m}, 6 \mathrm{H}, \mathrm{H}_{5}\right.$ and $\mathrm{H}_{5}$ ) , 7.72-7.69 (m, $3 \mathrm{H}, \mathrm{H}_{4}$ and $\left.\mathrm{H}_{4}\right), 1.47$ (s, 66H, $\mathrm{H}_{1}$ and $\mathrm{H}_{1}$, and $\left.\mathrm{H}_{15}\right)$ ppm. ${ }^{13} \mathrm{C}\left\{{ }^{1} \mathrm{H}\right\} \mathrm{NMR}\left(126 \mathrm{MHz}, \mathrm{CDCl}_{3}, 25{ }^{\circ} \mathrm{C}\right): \delta=$ 
149.0 $\left(\mathrm{C}^{3}\right.$ and $\left.\mathrm{C}^{3}\right), 144.2\left(\mathrm{C}^{10}\right), 142.9\left(\mathrm{C}^{\alpha}\right), 142.4\left(\mathrm{C}^{\alpha}\right), 140.1\left(\mathrm{C}^{6}\right.$ and $\left.\mathrm{C}^{6}\right), 133.4\left(\mathrm{C}^{11}\right.$ or $\left.\mathrm{C}^{12}\right), 133.3\left(\mathrm{C}^{11}\right.$ or $\left.\mathrm{C}^{12}\right), 132.6\left(\mathrm{C}^{\beta}\right), 132.5\left(\mathrm{C}^{\beta}\right), 132.4\left(\mathrm{C}^{\beta}\right), 131.9\left(\mathrm{C}^{\beta}\right), 128.9\left(\mathrm{C}^{5}\right), 128.8\left(\mathrm{C}^{5^{\prime}}\right), 121.2\left(\mathrm{C}^{4}\right.$ and $\left.\mathrm{C}^{4}\right), 120.3$ $\left(\mathrm{C}^{7}\right.$ and $\left.\mathrm{C}^{8}\right)$, $118.6\left(\mathrm{C}^{9}\right), 84.2\left(\mathrm{C}^{14}\right), 35.1\left(\mathrm{C}^{2}\right.$ and $\left.\mathrm{C}^{2}\right), 31.8\left(\mathrm{C}^{1}\right.$ and $\left.\mathrm{C}^{1}\right)$, $25.2\left(\mathrm{C}^{15}\right) \mathrm{ppm}$. UV/Vis $\left(\mathrm{CH}_{2} \mathrm{Cl}_{2}\right): \lambda_{\max }(\varepsilon)=417$ (324 000), $528 \mathrm{~nm}\left(23000 \mathrm{~mol}^{-1} \mathrm{dm}^{3} \mathrm{~cm}^{-1}\right)$. HRMS $\left(\mathrm{ESI}^{+}\right)$: calcd. for $\mathrm{C}_{74} \mathrm{H}_{88} \mathrm{BN}_{4} \mathrm{NiO}_{2}[\mathrm{MH}]^{+}$: 1133.6366, found 1133.6395.

\section{$\eta^{5}$-1,2,3,4,5-Penta-\{p-[nickel(II) $\quad 5,10,15$-tris(3,5-di-tert-butylphenyl) $\quad$ porphyrin-20-yl]-4,4'- biphenyl $\}$ cyclopentadienyl hydrotris $\{6-[($ ethylsulfanyl)methyl]indazol-1-yl $\}$ borate ruthenium(II) (12):}

In a dry Schlenk tube under argon, pentaaryl bromide $4 \mathbf{a}(10 \mathrm{mg}, 6.6 \mu \mathrm{mol}, 1.0$ equiv.), nickel porphyrin 11 (56 mg, $49.1 \mu \mathrm{mol}, 7.5$ equiv.), $\mathrm{Pd}(\mathrm{dppf}) \mathrm{Cl}_{2} \cdot \mathrm{CH}_{2} \mathrm{Cl}_{2}\left(2.7 \mathrm{mg}, 3.3 \mu \mathrm{mol}, 0.5\right.$ equiv.) and $\mathrm{Cs}_{2} \mathrm{CO}_{3}(26$ $\mathrm{mg}, 78.6 \mu \mathrm{mol}, 12$ equiv.) were successively introduced in $2 \mathrm{~mL}$ of a preliminary degassed solution of DMF and water (99:1). The resulting mixture was heated for $48 \mathrm{~h}$ at $100{ }^{\circ} \mathrm{C}$. The reaction mixture was then allowed to cool to room temperature and the solvents were evaporated in vacuo. The residue was adsorbed onto silica and further purified by column chromatography $\left(\mathrm{SiO}_{2}\right.$, heptane/ $\mathrm{CH}_{2} \mathrm{Cl}_{2}$ 4:1) to afford molecular gear $12(13.8 \mathrm{mg}, 2.2 \mu \mathrm{mol}, 34 \%)$ as a red solid. $R_{\mathrm{f}}=0.50$ (heptane $\left./ \mathrm{CH}_{2} \mathrm{Cl}_{2}, 1: 1\right)$; ${ }^{1} \mathrm{H}$ NMR (500 MHz, $\mathrm{CD}_{2} \mathrm{Cl}_{2}, 25^{\circ} \mathrm{C}$ ): $\delta=8.83-8.74\left(\mathrm{~m}, 40 \mathrm{H}, \mathrm{H}_{\beta}\right), 8.36$ (s, $\left.3 \mathrm{H}, \mathrm{H}_{1}\right), 8.15$ (br. s, $\left.3 \mathrm{H}, \mathrm{H}_{6}\right), 8.11$ (AA'BB' pattern, ${ }^{3} J=8.3 \mathrm{~Hz}, 10 \mathrm{H}, \mathrm{H}_{11}$ ), 8.02 (AA'BB' pattern, ${ }^{3} J=8.3 \mathrm{~Hz}, 10 \mathrm{H}, \mathrm{H}_{12}$ ), 7.95 (AA'BB' pattern, $\left.{ }^{3} J=8.5 \mathrm{~Hz}, 10 \mathrm{H}, \mathrm{H}_{13}\right), 7.88\left(\mathrm{~d},{ }^{4} J=1.9 \mathrm{~Hz}, 10 \mathrm{H}, \mathrm{H}_{5},\right), 7.85\left(\mathrm{~d},{ }^{4} J=1.9 \mathrm{~Hz}, 20 \mathrm{H}, \mathrm{H}_{5}\right), 7.83$ (AA'BB' pattern, $\left.{ }^{3} J=8.5 \mathrm{~Hz}, 10 \mathrm{H}, \mathrm{H}_{14}\right), 7.77\left(\mathrm{t},{ }^{4} J=1.9 \mathrm{~Hz}, 5 \mathrm{H}, \mathrm{H}_{4}{ }^{\prime \prime}\right), 7.70\left(\mathrm{t},{ }^{4} J=1.9 \mathrm{~Hz}, 10 \mathrm{H}, \mathrm{H}_{4}{ }^{\prime}\right.$ ), $7.57\left(\mathrm{~d},{ }^{3} J=8.5 \mathrm{~Hz}, 3 \mathrm{H}, \mathrm{H}_{3}\right), 7.12\left(\mathrm{~d},{ }^{3} J=8.5 \mathrm{~Hz}, 3 \mathrm{H}, \mathrm{H}_{4}\right), 4.01\left(\mathrm{~s}, 6 \mathrm{H}, \mathrm{H}_{8}\right), 2.56\left(\mathrm{q},{ }^{3} J=7.4 \mathrm{~Hz}, 6 \mathrm{H}\right.$, $\left.\mathrm{H}_{9}\right), 1.48$ (s, 90H, $\mathrm{H}_{1}$ ) $), 1.41$ (s, $\left.180 \mathrm{H}, \mathrm{H}_{1}\right), 1.34$ (t, $\left.{ }^{3} \mathrm{~J}=7.4 \mathrm{~Hz}, 9 \mathrm{H}, \mathrm{H}_{10}\right)$ ppm. ${ }^{13} \mathrm{C}\left\{{ }^{1} \mathrm{H}\right\} \mathrm{NMR}(126$ $\left.\mathrm{MHz}, \mathrm{CD}_{2} \mathrm{Cl}_{2}, 25^{\circ} \mathrm{C}\right): \delta=149.5\left(\mathrm{C}^{3 ”}\right), 149.4\left(\mathrm{C}^{3}\right), 144.3\left(\mathrm{C}^{2}\right), 143.3\left(\mathrm{C}^{\alpha}\right), 143.0\left(\mathrm{C}^{\alpha}\right), 141.1\left(\mathrm{C}^{1}\right), 140$. $7\left(\mathrm{C}^{10^{\prime}}\right), 140.4\left(\mathrm{C}^{6^{\prime \prime}}\right), 140.3\left(\mathrm{C}^{6^{\prime}}\right), 140.1\left(\mathrm{C}^{13^{3}}\right), 140.0\left(\mathrm{C}^{15}\right), 137.6\left(\mathrm{C}^{5}\right), 135.1\left(\mathrm{C}^{13}\right), 134.7\left(\mathrm{C}^{11^{1}}\right), 134.1$ $\left(C^{12}\right), 132.7\left(C^{\beta}\right), 132.6\left(C^{\beta}\right), 132.5\left(C^{\beta}\right), 132.1\left(C^{\beta}\right), 129.1\left(C^{5}\right), 129.1\left(C^{5^{\prime \prime}}\right), 126.6\left(C^{14}\right), 125.8\left(C^{12}\right)$, $122.9\left(C^{7}\right), 122.7\left(C^{3}\right), 121.8\left(C^{4 \prime}\right), 121.7\left(C^{4}\right), 120.7\left(C^{7}\right.$ and $\left.C^{8}\right), 120.6\left(C^{4}\right), 118.8\left(C^{9}\right), 111.7\left(C^{6}\right)$, $88.6\left(\mathrm{C}^{11}\right), 37.3\left(\mathrm{C}^{8}\right), 35.2\left(\mathrm{C}^{2 \prime}\right), 35.2\left(\mathrm{C}^{2}\right), 31.7\left(\mathrm{C}^{1}\right.$ ) and $\left.\mathrm{C}^{1{ }^{\prime \prime}}\right), 26.1\left(\mathrm{C}^{9}\right), 14.8\left(\mathrm{C}^{10}\right) \mathrm{ppm}$. UV/Vis $\left(\mathrm{CH}_{2} \mathrm{Cl}_{2}\right): \lambda_{\max }(\varepsilon)=418(1596000), 528 \mathrm{~nm}\left(117000 \mathrm{~mol}^{-1} \mathrm{dm}^{3} \mathrm{~cm}^{-1}\right)$. HRMS (MALDI): calcd. for $\mathrm{C}_{405} \mathrm{H}_{430} \mathrm{BN}_{26} \mathrm{Ni}_{5} \mathrm{RuS}_{3}[\mathrm{MH}]^{+}:$6155.9507, found 6155.9279.

\section{Nickel(II) 5-(4-ethynylphenyl)-10,15,20-tris(3,5-di-tert-butylphenyl) porphyrin (13):}

To a solution of freshly distilled pyrrole $\left(0.8 \mathrm{~mL}, 12.1 \mathrm{mmol}, 4.0\right.$ equiv.) in anhydrous $\mathrm{CHCl}_{3}(1.2 \mathrm{~L})$, 3,5-di-tert-butylbenzaldehyde ( $2.0 \mathrm{~g}, 9.17 \mathrm{mmol}, 3.0$ equiv.), 4-[(trimethylsilyl)ethynyl]benzaldehyde 15 (0.617 g, 3.04 mmol, 1.0 equiv.) and $\mathrm{BF}_{3} \cdot \mathrm{OEt}_{2}(1.19 \mathrm{~mL}, 9.47 \mathrm{mmol}, 3.1$ equiv.) were added under argon. After stirring the reaction mixture for $1 \mathrm{~h}$ at room temperature, DDQ (2.07 g, $9.11 \mathrm{mmol}, 3.0$ equiv.) was added and the mixture again stirred for $1 \mathrm{~h}$ at room temperature. In order to neutralize the Lewis acid, $\mathrm{Et}_{3} \mathrm{~N}(0.5 \mathrm{~mL})$ was added and the solution was stirred for $10 \mathrm{~min}$. The solvent was evaporated and the residue was purified by column chromatography $\left(\mathrm{SiO}_{2}\right.$, cyclohexane/ $\mathrm{CH}_{2} \mathrm{Cl}_{2}$ 5:1). The second band was collected to afford 5-[4-(trimethylsilylethynyl)phenyl]-10,15,20-tris(3,5-di-tertbutylphenyl)porphyrin in $8 \%$ yield $(264 \mathrm{mg}, 0.25 \mathrm{mmol})$. This porphyrin $(264 \mathrm{mg}, 0.25 \mathrm{mmol}, 1.0$ equiv.) was then dissolved in a $\mathrm{MeOH} / \mathrm{CH}_{2} \mathrm{Cl}_{2}$ (3:1) solution $(10 \mathrm{~mL})$ and $\mathrm{K}_{2} \mathrm{CO}_{3}(104 \mathrm{mg}, 0.76 \mathrm{mmol}$, 3.0 equiv.) was added. After stirring for $12 \mathrm{~h}$ at room temperature, the solution was quenched with $\mathrm{H}_{2} \mathrm{O}$ and the aqueous layer was extracted with $\mathrm{CH}_{2} \mathrm{Cl}_{2}$. The combined organic layers were then washed with brine, dried on $\mathrm{Na}_{2} \mathrm{SO}_{4}$, filtered and the solvent was removed in vacuum affording 5-(4-ethynylphenyl)10,15,20-tris(3,5-di-tert-butylphenyl)porphyrin $(241 \mathrm{mg}, 0.24 \mathrm{mmol}, 98 \%)$ as a purple solid. In a dry Schlenk tube under argon, a solution of this free-base porphyrin (104 mg, $0.107 \mathrm{mmol}, 1.0$ equiv.) and nickel(II) acetylacetonate $\mathrm{Ni}(\mathrm{acac})_{2}(110 \mathrm{mg}, 0.426 \mathrm{mmol}, 4.0$ equiv. $)$ in dry toluene $(20 \mathrm{~mL})$ was heated at $110{ }^{\circ} \mathrm{C}$ overnight. Then the mixture was cooled to room temperature and volatiles were evaporated. 
The crude product was purified by column chromatography $\left(\mathrm{SiO}_{2}\right.$, cyclohexane $/ \mathrm{CH}_{2} \mathrm{Cl}_{2}$ 7:3) to yield nickel porphyrin $13(104 \mathrm{mg}, 0.102 \mathrm{mmol}, 95 \%)$ as a red solid. $R_{\mathrm{f}}=0.80$ (cyclohexane $\left./ \mathrm{CH}_{2} \mathrm{Cl}_{2}, 2: 1\right)$; ${ }^{1} \mathrm{H}$ NMR $\left(500 \mathrm{MHz}, \mathrm{CDCl}_{3}, 25{ }^{\circ} \mathrm{C}\right): \delta=8.81\left(\mathrm{~m}, 4 \mathrm{H}, \mathrm{H}_{\beta}\right), 8.80\left(\mathrm{~d},{ }^{3} J=4.9 \mathrm{~Hz}, 2 \mathrm{H}, \mathrm{H}_{\beta}\right), 8.71\left(\mathrm{~d},{ }^{3} J=4.9\right.$ $\left.\mathrm{Hz}, 2 \mathrm{H}, \mathrm{H}_{\beta}\right), 8.00\left(\mathrm{AA}^{\prime} \mathrm{BB}^{\prime}\right.$ pattern, $\left.{ }^{3} J=8.4 \mathrm{~Hz}, 2 \mathrm{H}, \mathrm{H}_{11}\right), 7.89-7.86\left(\mathrm{~m}, 6 \mathrm{H}, \mathrm{H}_{5}\right.$ and $\left.\mathrm{H}_{5}{ }^{\prime}\right), 7.81$ (AA'BB' pattern, $\left.{ }^{3} J=8.4 \mathrm{~Hz}, 2 \mathrm{H}, \mathrm{H}_{12}\right), 7.74-7.71\left(\mathrm{~m}, 3 \mathrm{H}, \mathrm{H}_{4}\right.$ and $\left.\mathrm{H}_{4}{ }^{\prime}\right), 3.27\left(\mathrm{~s}, 1 \mathrm{H}, \mathrm{H}_{15}\right), 1.48\left(\mathrm{~s}, 54 \mathrm{H}, \mathrm{H}_{1}\right.$ and $\left.\mathrm{H}_{1^{\prime}}\right)$ ppm. ${ }^{13} \mathrm{C}\left\{{ }^{1} \mathrm{H}\right\}$ NMR $\left(126 \mathrm{MHz}, \mathrm{CDCl}_{3}, 25{ }^{\circ} \mathrm{C}\right): \delta=149.1\left(\mathrm{C}^{3}\right.$ and $\left.\mathrm{C}^{3}\right), 143.0\left(\mathrm{C}^{\alpha}\right), 142.9\left(\mathrm{C}^{\alpha}\right), 142.2$ $\left(\mathrm{C}^{\alpha}\right), 142.0\left(\mathrm{C}^{10}\right), 140.1\left(\mathrm{C}^{6}\right.$ and $\left.\mathrm{C}^{6}\right), 133.8\left(\mathrm{C}^{11}\right), 132.7\left(\mathrm{C}^{\beta}\right), 132.6\left(\mathrm{C}^{\beta}\right), 132.5\left(\mathrm{C}^{\beta}\right), 131.6\left(\mathrm{C}^{\beta}\right), 130.8$ $\left(\mathrm{C}^{12}\right), 128.9\left(\mathrm{C}^{5}\right), 128.8\left(\mathrm{C}^{5}\right), 121.6\left(\mathrm{C}^{13}\right), 121.3\left(\mathrm{C}^{4}\right.$ and $\left.\mathrm{C}^{4}\right), 120.5\left(\mathrm{C}^{8}\right), 120.4\left(\mathrm{C}^{7}\right), 117.6\left(\mathrm{C}^{9}\right), 83.8$ $\left(\mathrm{C}^{14}\right), 78.2\left(\mathrm{C}^{15}\right), 35.1\left(\mathrm{C}^{2}\right.$ and $\left.\mathrm{C}^{2}\right), 31.8\left(\mathrm{C}^{1}\right.$ and $\left.\mathrm{C}^{1}\right) \mathrm{ppm}$. UV/Vis $\left(\mathrm{CH}_{2} \mathrm{Cl}_{2}\right): \lambda_{\max }(\varepsilon)=417(248000)$, $528 \mathrm{~nm}\left(18000 \mathrm{~mol}^{-1} \mathrm{dm}^{3} \mathrm{~cm}^{-1}\right)$. HRMS $\left(\mathrm{ESI}^{+}\right)$: calcd. for $\mathrm{C}_{70} \mathrm{H}_{77} \mathrm{~N}_{4} \mathrm{Ni}[\mathrm{MH}]^{+}$: 1031.5502, found 1031.5498. The data match those reported in the literature. ${ }^{[25]}$

\section{$\eta^{5}$-1,2,3,4,5-Penta-\{p-[nickel(II) 10,15,20-tris(3,5-di-tert-butylphenyl) porphyrin-5- yl]phenylethynylphenyl $\}$ cyclopentadienyl hydrotris $\{6-[($ ethylsulfanyl)methyl $]$ indazol-1-yl $\}$ borate ruthenium(II) (14):}

In a dry Schlenk tube under argon, pentaaryl iodide $\mathbf{4 b}(10 \mathrm{mg}, 5.7 \mu \mathrm{mol}, 1.0$ equiv.), nickel porphyrin 13 (44 mg, $42.6 \mu \mathrm{mol}, 7.5$ equiv.), $\mathrm{Pd}\left(\mathrm{PPh}_{3}\right)_{2} \mathrm{Cl}_{2}(2 \mathrm{mg}, 2.85 \mu \mathrm{mol}, 0.5$ equiv.) and $\mathrm{CuI}(0.3 \mathrm{mg}, 1.7$ $\mu \mathrm{mol}, 0.3$ equiv.) were successively introduced and dry $\mathrm{NEt}_{3}(2 \mathrm{~mL})$ was added. The resulting mixture was degassed for $15 \mathrm{~min}$ and then heated for $24 \mathrm{~h}$ at $45^{\circ} \mathrm{C}$. After evaporation, the residue was adsorbed onto silica and further purified by column chromatography $\left(\mathrm{SiO}_{2}\right.$, cyclohexane/ $\left.\mathrm{CH}_{2} \mathrm{Cl}_{2} 4: 1\right)$ to afford molecular gear 14 (22 mg, $3.5 \mu \mathrm{mol}, 62 \%)$ as a red solid. $R_{\mathrm{f}}=0.50\left(\right.$ cyclohexane/ $\left.\mathrm{CH}_{2} \mathrm{Cl}_{2}, 2: 1\right)$; ${ }^{1} \mathrm{H} \mathrm{NMR}$ $\left(500 \mathrm{MHz}, \mathrm{CD}_{2} \mathrm{Cl}_{2}, 25^{\circ} \mathrm{C}\right.$ ): $\delta=8.80-8.75\left(\mathrm{~m}, 40 \mathrm{H}, \mathrm{H}_{\beta}\right), 8.29$ (br. s, $\left.3 \mathrm{H}, \mathrm{H}_{6}\right), 8.13\left(\mathrm{~s}, 3 \mathrm{H}, \mathrm{H}_{1}\right), 8.04$ (AA'BB' pattern, $\left.{ }^{3} J=8.4 \mathrm{~Hz}, 10 \mathrm{H}, \mathrm{H}_{11}{ }^{\prime}\right), 7.90-7.85\left(\mathrm{~m}, 40 \mathrm{H}, \mathrm{H}_{12}\right.$ ' and $\mathrm{H}_{5}$, and $\mathrm{H}_{5}$ '), $7.77\left(\mathrm{t},{ }^{4} \mathrm{~J}=1.8 \mathrm{~Hz}\right.$, $\left.5 \mathrm{H}, \mathrm{H}_{4}{ }^{\prime}\right), 7.73\left(\mathrm{t},{ }^{4} J=1.8 \mathrm{~Hz}, 10 \mathrm{H}, \mathrm{H}_{4}{ }^{\prime}\right), 7.63$ (AA'BB' pattern, $\left.{ }^{3} J=8.3 \mathrm{~Hz}, 10 \mathrm{H}, \mathrm{H}_{13}\right), 7.54\left(\mathrm{~d}^{3},{ }^{3} J=8.6\right.$ $\left.\mathrm{Hz}, 3 \mathrm{H}, \mathrm{H}_{3}\right), 7.50\left(\mathrm{AA}^{\prime} \mathrm{BB}^{\prime}\right.$ pattern, $\left.{ }^{3} J=8.3 \mathrm{~Hz}, 10 \mathrm{H}, \mathrm{H}_{14}\right), 7.10\left(\mathrm{~d},{ }^{3} J=8.6 \mathrm{~Hz}, 3 \mathrm{H}, \mathrm{H}_{4}\right), 4.07(\mathrm{~s}, 6 \mathrm{H}$, $\left.\mathrm{H}_{8}\right), 2.61$ (q, $\left.{ }^{3} J=7.4 \mathrm{~Hz}, 6 \mathrm{H}, \mathrm{H}_{9}\right), 1.48\left(\mathrm{~s}, 90 \mathrm{H}, \mathrm{H}_{1}{ }^{\prime}\right), 1.44$ (s, $\left.180 \mathrm{H}, \mathrm{H}_{1}{ }^{\prime}\right), 1.36\left(\mathrm{t},{ }^{3} J=7.4 \mathrm{~Hz}, 9 \mathrm{H}, \mathrm{H}_{10}\right)$ ppm. ${ }^{13} \mathrm{C}\left\{{ }^{1} \mathrm{H}\right\}$ NMR $\left(126 \mathrm{MHz}, \mathrm{CD}_{2} \mathrm{Cl}_{2}, 25^{\circ} \mathrm{C}\right): \delta=149.5\left(\mathrm{C}^{3}\right.$ and $\left.\mathrm{C}^{3}{ }^{\prime \prime}\right), 144.3\left(\mathrm{C}^{2}\right), 143.4\left(\mathrm{C}^{\alpha}\right), 143.3$ $\left(C^{\alpha}\right), 142.8\left(C^{\alpha}\right), 141.7\left(C^{10^{\prime}}\right), 140.9\left(C^{1}\right), 140.3\left(C^{6^{\prime \prime}}\right), 140.3\left(C^{6}\right), 137.4\left(C^{5}\right), 134.6\left(C^{12}\right), 134.2\left(C^{13}\right.$ and $\left.C^{11^{\prime}}\right), 132.8\left(C^{\beta}\right), 132.6\left(C^{\beta}\right), 131.9\left(C^{\beta}\right), 131.3\left(C^{14}\right), 130.5\left(C^{12^{\prime}}\right), 129.1\left(C^{5}\right), 129.1\left(C^{5 "}\right), 123.0$ $\left(\mathrm{C}^{13^{\prime}}\right), 122.9\left(\mathrm{C}^{7}\right.$ and $\left.\mathrm{C}^{4}\right), 122.8\left(\mathrm{C}^{15}\right), 121.8\left(\mathrm{C}^{4}\right.$ and $\left.\mathrm{C}^{4^{\prime \prime}}\right), 120.9\left(\mathrm{C}^{8^{\prime}}\right), 120.8\left(\mathrm{C}^{7}\right), 120.5\left(\mathrm{C}^{3}\right), 118.3$ $\left(\mathrm{C}^{9}\right), 112.1\left(\mathrm{C}^{6}\right), 90.7\left(\mathrm{C}^{15^{\prime}}\right), 90.5\left(\mathrm{C}^{14^{\prime}}\right), 88.3\left(\mathrm{C}^{11}\right), 37.5\left(\mathrm{C}^{8}\right), 35.3\left(\mathrm{C}^{2^{\prime}}\right.$ and $\left.\mathrm{C}^{2 \prime}\right), 31.8\left(\mathrm{C}^{1}\right.$ and $\left.\mathrm{C}^{1 \text { "' }}\right)$, $26.6\left(\mathrm{C}^{9}\right), 14.7\left(\mathrm{C}^{10}\right)$ ppm. UV/Vis $\left(\mathrm{CH}_{2} \mathrm{Cl}_{2}\right): \lambda_{\max }(\varepsilon)=418(1390000), 529 \mathrm{~nm}(103000$ $\left.\mathrm{mol}^{-1} \mathrm{dm}^{3} \mathrm{~cm}^{-1}\right) . \mathrm{CV}\left(\mathrm{CH}_{2} \mathrm{Cl}_{2}, n \mathrm{Bu}_{4} \mathrm{NPF}_{6}, 0.1 \mathrm{~V} \mathrm{~s}^{-1}\right), E_{1 / 2}$ (V/SCE): +0.78 rev (1e), +0.97 rev (10e). HRMS (MALDI): calcd. for $\mathrm{C}_{415} \mathrm{H}_{430} \mathrm{BN}_{26} \mathrm{Ni}_{5} \mathrm{RuS}_{3}[\mathrm{MH}]^{+}$: 6275.9507, found 6275.9233.

\section{4-[2-(Trimethylsilyl)ethynyl]benzaldehyde (15):}

In a dry Schlenk tube under argon, 4-bromobenzaldehyde (3.5 g, 19 mmol, 1.0 equiv.), $\mathrm{Pd}\left(\mathrm{PPh}_{3}\right)_{2} \mathrm{Cl}_{2}$ ( $80 \mathrm{mg}, 0.11 \mathrm{mmol}, 0.6 \mathrm{~mol} \%)$ and $\mathrm{CuI}(11 \mathrm{mg}, 0.06 \mathrm{mmol}, 0.3 \mathrm{~mol} \%)$ were successively introduced, followed by $\mathrm{NEt}_{3}(10 \mathrm{~mL})$, THF $(10 \mathrm{~mL})$ and ethynyltrimethylsilane $(3.24 \mathrm{~mL}, 22.8 \mathrm{mmol}, 1.2$ equiv.). The system was then degassed and heated overnight at $45{ }^{\circ} \mathrm{C}$. After evaporation, the residue was adsorbed onto silica and purified by column chromatography $\left(\mathrm{SiO}_{2}\right.$, heptane/ $\left.\mathrm{CH}_{2} \mathrm{Cl}_{2} 2: 1\right)$ to afford the desired product $15(3.7 \mathrm{~g}, 18.3 \mathrm{mmol}, 97 \%)$ as a white powder. $R_{\mathrm{f}}=0.40$ (heptane $\left./ \mathrm{CH}_{2} \mathrm{Cl}_{2}, 2: 1\right)$; ${ }^{1} \mathrm{H}$ NMR (300 MHz, $\mathrm{CDCl}_{3}, 25^{\circ} \mathrm{C}$ ): $\delta=10.00\left(\mathrm{~s}, 1 \mathrm{H}, \mathrm{CHO}\right.$ ), 7.81 (AA'BB' pattern, ${ }^{3} \mathrm{~J}=8.5 \mathrm{~Hz}, 2 \mathrm{H}$, CHAr), 7.60 (AA'BB' pattern, $\left.{ }^{3} J=8.5 \mathrm{~Hz}, 2 \mathrm{H}, \mathrm{CHAr}\right), 0.26\left(\mathrm{~s}, 9 \mathrm{H}, \mathrm{CH}_{3}\right) \mathrm{ppm}$. The data match those reported in the literature. ${ }^{[26]}$ 


\section{Acknowledgements}

This work was supported by the University Paul Sabatier (Toulouse, France) and the Centre National de la Recherche Scientifique (CNRS). It has received funding from the Agence Nationale de la Recherche (ANR) (ACTION project ANR-15-CE29-0005) and from the European Union's Horizon 2020 research and innovation programme under the project MEMO, grant agreement No 766864. This research was also partly supported by the JSPS KAKENHI grant in aid for Scientific Research on Innovative Areas "Molecular Engine (No.8006)" 18H05419. Y.G. thanks the French Ministry of National Education for a PhD Fellowship. Dr. Colin Martin is warmly acknowledged for his careful reading and improving of our manuscript and Dr. Jacques Bonvoisin is acknowledged for his expertise regarding cyclic voltammetry experiments.

\section{References and Notes}

[1] Y. Kawada, H. Iwamura, J. Org. Chem. 1980, 45, 2547-2548.

[2] W. D. Hounshell, C. A. Johnson, A. Guenzi, F. Cozzi, K. Mislow, Proc. Natl. Acad. Sci USA 1980, 77, 69616964.

[3] A. M. Stevens, C. J. Richards, Tetrahedron Lett. 1997, 38, 7805-7808.

[4] D. K. Frantz, A. Linden, K. K. Baldridge, J. S. Siegel, J. Am. Chem. Soc. 2012, 134, 1528-1535.

[5] H. Ube, Y. Yasuda, H. Sato, M. Shionoya, Nature Commun. 2017, 8, 14296.

[6] F. Chiaravalloti, L. Gross, K.-H. Rieder, S. M. Stojkovic, A. Gourdon, C. Joachim, F. Moresco, Nature Mater. 2007, 6, 30-33.

[7] C. Manzano, W.-H. Soe, H. S. Wong, F. Ample, A. Gourdon, N. Chandrasekhar, C. Joachim, Nature Mater. 2009, 8, 576-579.

[8] C. Kammerer, G. Rapenne, Eur. J. Inorg. Chem. 2016, 2214-2226.

[9] U.G.E. Perera, F. Ample, H. Kersell, Y. Zhang, G. Vives, J. Echeverria, M. Grisolia, G. Rapenne, C. Joachim, S.-W. Hla, Nature Nanotechnol. 2013, 8, 46-51.

[10] G. Erbland, Y. Gisbert, G. Rapenne, C. Kammerer, Eur. J. Org. Chem. 2018, 4731-4739.

[11] E.-I. Negishi in Handbook of Organopalladium Chemistry for Organic Synthesis, Vol. 1 (Ed.: E.-I. Negishi), John Wiley \& Sons, Inc, New York, 2002, pp. 215-227.

[12] A. Carella, J.-P. Launay, R. Poteau, G. Rapenne, Chem. Eur. J. 2008, 14, 8147-8156.

[13] A. Klapars, S. L. Buchwald, J. Am. Chem. Soc. 2002, 124, 14844-14845.

[14] B. H. Yang, S. L. Buchwald, J. Organomet. Chem. 1999, 576, 125-146.

[15] A. Klapars, J. C. Antilla, X. Huang, S. L. Buchwald, J. Am. Chem. Soc. 2001, 123, 7727-7729.

[16] A. Klapars, X. Huang, S. L. Buchwald, J. Am. Chem. Soc. 2002, 124, 7421-7428.

[17] M. Koepf, A. Trabolsi, M. Elhabiri, J. A. Wytko, D. Paul, A. M. Albrecht-Gary, J. Weiss, Org. Lett. 2005, 7, 1279-1282.

[18] E. Avellanal-Zaballa, G. Duran-Sampedro, A. Prieto-Castaneda, A. R. Agarrabeitia, I. Garcia-Moreno, I. Lopez-Arbeloa, J. Banuelos, M. J. Ortiz, Phys. Chem. Chem. Phys. 2017, 19, 13210-13218.

[19] H. Marbach, Acc. Chem. Res. 2015, 48, 2649-2658.

[20] J. S. Lindsey, H. C. Hsu, I. C. Schreiman, Tetrahedron Lett. 1986, 27, 4969-4970.

[21] R. Chinchilla, C. Najera, Chem. Rev. 2007, 107, 874-922.

[22] Bruker, SADABS, Bruker AXS Inc., Madison, Wisconsin, USA, 2008.

[23] ShelXT, G. M. Sheldrick, University of Göttingen, Acta Crystallogr. Sect. A, 2015, 71, 3-8.

[24] ShelXL, G. M. Sheldrick, University of Göttingen, Acta Crystallogr. Sect. C, 2015, 71, 3-8.

[25] M. M. Martin, M. Dill, J. Langer, N. Jux, J. Org. Chem. 2019, 84, 1489-1499.

[26] S. Thorand, N. Krause, J. Org. Chem. 1998, 63, 8551-8553. 